Article

\title{
Buds, Bugs and Bienniality: The Floral Biology of Eschweilera tenuifolia (O. Berg) Miers in a Black-Water Flooded Forest, Central Amazonia
}

\author{
Adrian A. Barnett ${ }^{1,2,3,4, *}$, Sarah A. Boyle ${ }^{5}{ }^{(0}$, Natalia M. Kinap ${ }^{6}$, \\ Tereza Cristina dos Santos-Barnett ${ }^{7}$, Thiago Tuma Camilo ${ }^{8}{ }^{\circledR}$, Pia Parolin ${ }^{9}$, \\ Maria Teresa Fernandez Piedade ${ }^{10} \mathbb{D}$ and Bruna $M$. Bezerra ${ }^{1}$ (D) \\ 1 Department of Zoology, Federal University of Pernambuco, 50670-420 Recife, Pernambuco, Brazil; \\ brunamb1234@gmail.com \\ 2 Department of Botany, National Amazon Research Institute, 69067-375 Manaus, Amazonas, Brazil \\ 3 Department of Biology, Amazonas Federal University, 69077-000 Manaus, Amazonas, Brazil \\ Department of Life Sciences, Roehampton University, London SW15 5PJ, UK \\ Department of Biology, Rhodes College, Memphis, TN 38112, USA; sarahannboyle@gmail.com \\ 6 Amazon Mammals Research Group, National Amazon Research Institute, \\ 69067-375 Manaus, Amazonas, Brazil; nataliakinap@gmail.com \\ 7 Department of Nutrition, Manaus Central University-FAMETRO, 69050-000 Manaus, Amazonas, Brazil; \\ terezacristina1996@gmail.com \\ 8 Department of Chemical Engineering, Federal University of Amazonas, \\ 69077-000 Manaus, Amazonas, Brazil; thiagotumaa@gmail.com \\ 9 Biodiversity, Evolution and Ecology of Plants (BEE), University of Hamburg, 20146 Hamburg, Germany; \\ piaparolin@gmx.de \\ 10 Ecology, Monitoring and Sustainable Use of Wetlands Research Group (MAUA), National Amazon \\ Research Institute, 69067-375 Manaus, Amazonas, Brazil; maitepp@inpa.gov.br \\ * Correspondence: adrian.barnett1@gmail.com
}

Received: 23 September 2020; Accepted: 14 November 2020; Published: 25 November 2020

\begin{abstract}
Research Highlights: Our study establishes the biennial nature of flowering intensity as a life-time energy-conserving strategy; we show unexpectedly high flower:fruit ratios despite extensive predation of buds and flowers by insect larvae; 'selective' bud abortion may be a key annual energy-saving strategy. Background and Objectives: We aim to explain the strongly biennial flowering pattern of Eschweilera tenuifolia, an ecologically key tree species of Amazon blackwater-flooded forest, inundated for up to nine months annually, and with large flowers (6 $\mathrm{cm}$ in width). Materials and Methods: We quantified the insect infestation of central Amazonian Eschweilera tenuifolia buds and flowers; we measured nectar production from flower opening onwards, examined flower duration and monitored pollen theft. We tested the role of infestation in bud abortion, nectar production and fruit production initiation. Results: Our study shows extensive predation of buds and flowers by insect larvae, as well as selective abortion of heavily infested buds, and limited loss to pollen thieves which fed largely on infertile fodder pollen. Nectar production peaked in the morning, with no nocturnal nectar production recorded. Sucrose levels were similar to congeneric values (mean $37.4 \%$ ), and near-constant during production. Flower duration (4-5 days) was longer than reported for other congenerics. Conclusions: Insect infestation of buds can play an important role in regulating flower:fruit ratios, thus setting limits on individual total seed set. Individual Eschweilera tenuifolia appear to invest highly in reproduction every second year. Extended flower duration may be a strategy to enhance pollination success, but increases overall reproductive investment. Abortion of heavily infested buds may minimize allocation of energy to malformed flowers, which have a lower chance of attracting pollinators, thus functioning as a short-term energy-saving strategy. Additionally, biennial flowering in E. tenuifolia is likely to be an energy-conserving response in a
\end{abstract}


highly physiologically-challenging environment. Thus, E. tenuifolia exhibits energy-conservation strategies at two divergent temporal scales.

Keywords: nectar production; bud abortion; insects; invertebrate bud predation; flower:fruit ratio; igapó; reproductive strategy

\section{Introduction}

The Lecythidaceae is a tropical plant family of 300 species in 20 genera and three subfamilies [1], of which one, Lecythidoideae, is exclusively neotropical. One genus in the Lecythidoideae, Eschweilera, is a speciose clade of trees (94 species: Mori and Prance [2,3]; Tropicos [4]—though see Mori et al. [1]). Although the genus occurs from southern Mexico (E. mexicana T. Wendt, S.A. Mori and Prance) to southern Brazil (E. compressa [Vell.] Miers) and Trinidad (3 spp., incl. E. decolorans Sandwith), Eschweilera has its greatest diversity in the Amazon basin [2]. The lowland Amazon may have 6-17 sympatric congeneric species in unflooded lowland forest (terra firme) [5-7], and members of the genus may dominate both numerically and by Importance Value Index [6-10]. Indeed, Eschweilera coriacea is considered by ter Steege et al. [11] to be one of the Amazon's hyper-dominant tree species. While the majority of Eschweilera species occupy terra firme and other non-flooded habitats, a few species (e.g., E. ovifolia (DC.) Nied., E. parviflora (Aubl.) Miers, E. pedicellata (Rich.) S.A. Mori, and E. tenuifolia [O. Berg] Miers) occupy the seasonally-flooded forests of the Amazon basin.

Here we report on the flowering phenology, patterns of nectar production and animal interactions for E. tenuifolia, a species which inhabits seasonally-flooded forest present on the margins of low-sediment, clear, and blackwater rivers (igapó-sensu Prance 1979: as clear and blackwater forms of igapó are floristically distinct, we will use the word 'igapó' in this paper to refer purely to the seasonally-flooded forests on the margins of blackwater rivers) (Figure 1A).

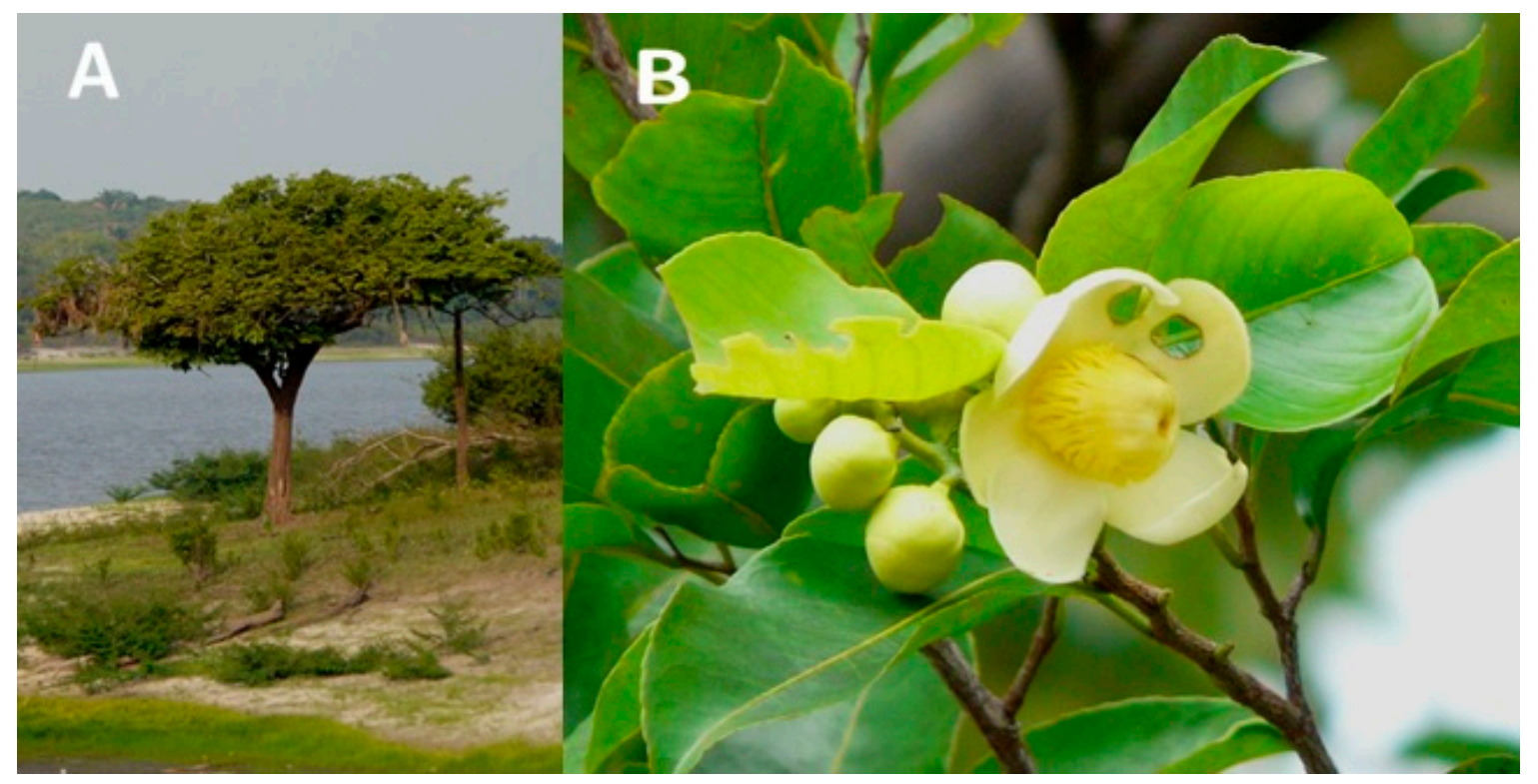

Figure 1. (A) An isolated individual of Eschweilera tenuifolia in the low water season. Flood water will touch the underside of the canopy when river-levels are highest. (B) Inflorescence of E. tenuifolia, showing buds at varying stages of development, and open flower with clearly visible androecium. Photos: Daniel Praia.

Eschweilera tenuifolia occurs in the igapós of central Amazonia, where it is a dominant member of the plant assemblage and an important species in the general ecology of the region. It is a key 
component in the diet of primates, parrots, macaws, and moths, and forms part of the diet of arboreal rodents [12,13] (Table 1). Trunks of large trees are hollow and provide roosts for bats and other mammals (Table 1). Following seed shed, those parts of dehisced fruits that remain on trees are used as refuges by invertebrates for nests (wasps and ants) and webs (spiders; Table 1). Seven igapó-inhabiting species of the genus Eschweilera are known to harbor galls on the leaves and bud tips [14]. Although E. tenuifolia is the most abundan $t$ member of this genus in igapó [15], insect galls have not been documented in this species, which may, potentially, be due to the high level of bioactive chemicals in E. tenuifolia [16]. However, despite the presence of chemical substances, the species interacts with other igapó plants alone or in association with animals (Tables 1 and 2).

Table 1. Interactions between Eschweilera tenuifolia (Lecythidaceae) and igapó animals.

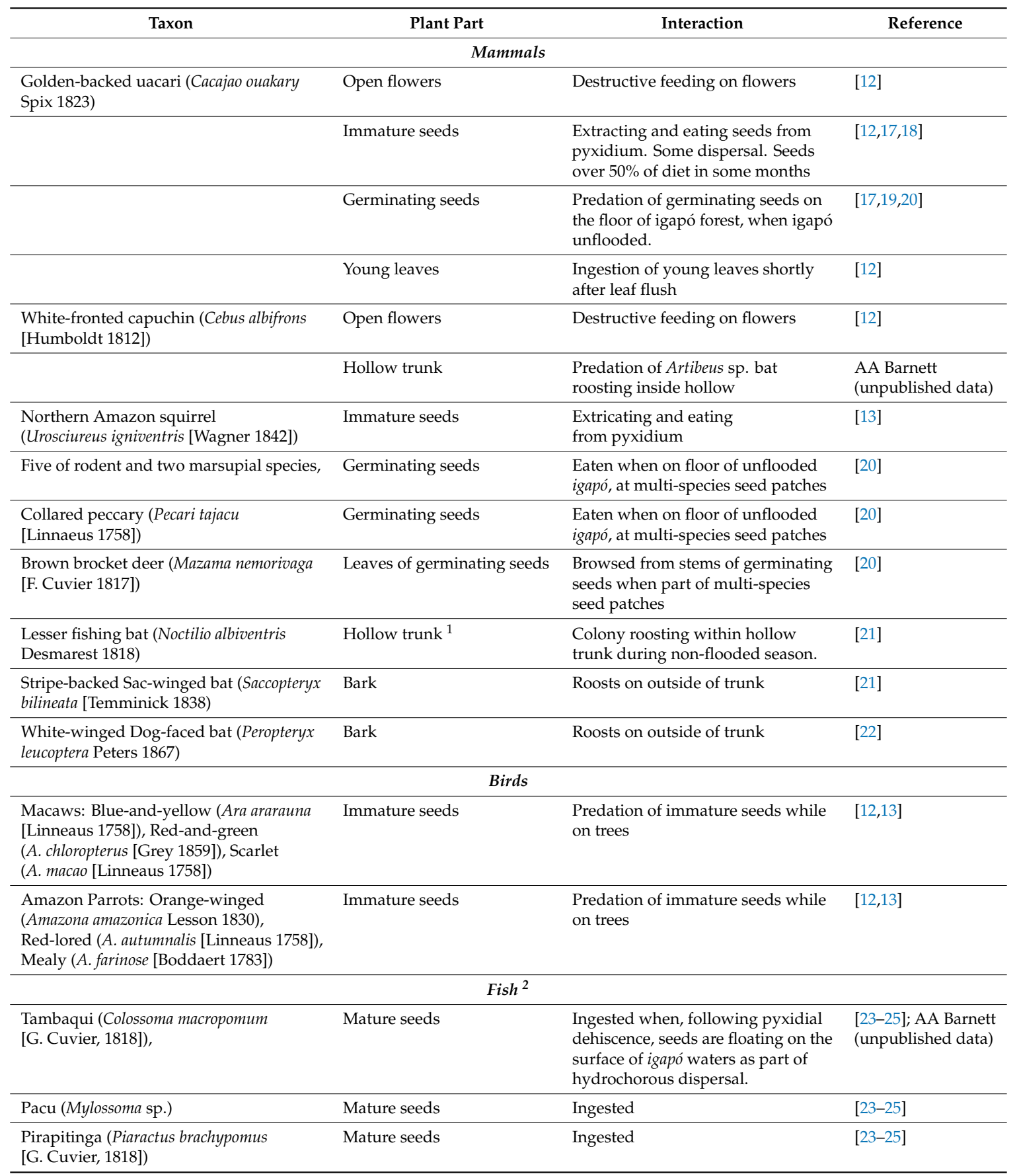


Table 1. Cont.

\begin{tabular}{|c|c|c|c|}
\hline Taxon & Plant Part & Interaction & Reference \\
\hline \multicolumn{4}{|c|}{ Invertebrates } \\
\hline Freshwater sponges (Demospongiae) & Trunks below flood line & $\begin{array}{l}\text { A generalist interaction as sponges } \\
\text { also use many other trunks as a } \\
\text { growth substrate. }\end{array}$ & {$[26,27]$} \\
\hline $\begin{array}{l}\text { Hunting spiders (Ancylometes sp. } \\
\text { Pisauridae: possibly A. jau [28]). }\end{array}$ & $\begin{array}{l}\text { Trunks just above the current } \\
\text { waterline }\end{array}$ & $\begin{array}{l}\text { A generalist interaction, as these } \\
\text { arachnids also use many other } \\
\text { trunks as resting and hunting } \\
\text { substrates. }\end{array}$ & [28] \\
\hline $\begin{array}{l}\text { Ant (Dolichoderus bispinosus } \\
\text { [Olivier, 1792]) }\end{array}$ & Developing pyxidia & $\begin{array}{l}\text { Seen feeding on unidentified } \\
\text { material on pyxidia surfaces } \\
\text { (possibly exudate from insect } \\
\text { boreholes). The species is } \\
\text { aggressive, widespread and } \\
\text { exclusively arboreal. }\end{array}$ & [29] \\
\hline $\begin{array}{l}\text { Moths (four morpho- } \\
\text { species)—caterpillars }\end{array}$ & Developing pyxidia & $\begin{array}{l}\text { Found within the developing } \\
\text { pyxidia }\end{array}$ & $\begin{array}{l}\text { AA Barnett \& } \\
\text { RHP da Silva } \\
\text { (unpublished data) }\end{array}$ \\
\hline Seed weevil (Buchinae) & Developing pyxidia & $\begin{array}{l}\text { Found within the developing } \\
\text { pyxidia }\end{array}$ & $\begin{array}{l}\text { AA Barnett \& } \\
\text { RHP da Silva } \\
\text { (unpublished data) }\end{array}$ \\
\hline $\begin{array}{l}\text { Centipedes, woodlice, scorpions, } \\
\text { pseudoscorpions, ants and beetles }\end{array}$ & $\begin{array}{l}\text { Pyxidia with damaged } \\
\text { and/or rotting seeds and } \\
\text { partly broken excarp }\end{array}$ & Live in pyxidia & $\begin{array}{l}\text { AA Barnett \& } \\
\text { RHP da Silva } \\
\text { (unpublished data) }\end{array}$ \\
\hline $\begin{array}{l}\text { Stingless Bees (Melipona and } \\
\text { Scaptotrigona spp.) }\end{array}$ & Pollen and nectar & $\begin{array}{l}\text { Known to remove pollen from } \\
\text { E. tenuifolia flowers, but may not } \\
\text { be effective pollinators }\end{array}$ & [32] \\
\hline
\end{tabular}

${ }^{1}$ The hollow nature of their trunks means that terra firme members of the genus are used in this way by bats [22,33].

2 In other flooded forest species, such as E. ovalifolia, seeds are surrounded by a thin white fleshy sarcotesta, and the seeds are ingested, then dispersed, by fish [34]. However, E. tenuifolia lacks any such arilate tissue and the seed coat is corky and acts only as a floatation device [35]. Seeds of E. tenuifolia are also considerablly larger than those of E. ovalifolia (2.8-5 cm length vs. 3-3.5 cm diameter: [35]. This, plus their respective shapes (fusiform vs. pulviniform), means that observed fish-seed interactions for E. tenuifolia (e.g., with Colossoma macropomum, a typical igapó seed predator fish: [25]), were likely to be purely predatory. ${ }^{3}$ While larvae of most members of this family are wood-borers, several exploit hard seeds [36]. Species of the genus Carmenta have been raised from seeds from a variety of Neotropical plant families, including Lecythidaceae (Eschweilera and Gustavia: [37]). 4 Though larval sessids, attributed to the genus Carmenta were recorded by both Maia [31] and Barnett [12] from E. tenuifolia seeds, the illustrated adults have different appearances. As the study sites were on opposite sides of the Rio Negro, they may represent different taxa. ${ }^{5}$ Similar interactions occur with the pyxidea of terra firme species, except that, instead of providing rain-shelters they often provide pools of water on the otherwise pool-less forest floor (e.g., Bertholletia excelsa [38]; Gustavia superba [39]).

The igapó forest inhabited by E. tenuifolia is inundated for up to 10 months of the year by floodwaters up to $7 \mathrm{~m}$ (Figure 1A). Consequently, igapó forest tree species show a variety of physiological and anatomical adaptations to this extended flooding and accompanying anoxia [40]. 
Table 2. Interactions between Eschweilera tenuifolia (Lecythidaceae) and other igapó plants, and subsequent interactions with igapó animals.

\begin{tabular}{|c|c|c|}
\hline Type of Plant & Interactions & Reference \\
\hline $\begin{array}{l}\text { Wide-ranging, sun-tolerant species } \\
\text { such as Philodendrum solimoesensis } \\
\text { A.C. Sm (Arecaceae) and } \\
\text { Aechmea mertensii (G. Mey.) Schult. } \\
\text { \& Schult.f (Bromeliaceae). }\end{array}$ & $\begin{array}{l}\text { Pionus parrots and Saimiri monkeys seen eating } \\
\text { infusctescences of P. solimoensis on E. tenuifolia. An } \\
\text { unidentified hummingbird was seen visiting A. } \\
\text { mertensii inflorescences on several occasions. Cacajao } \\
\text { ouakary ate the leaf bases of } A \text {. mertensii-though it } \\
\text { was unclear if this was for the succulent water-rich } \\
\text { material there, or the larvae of Metamasius weevils } \\
\text { known to inhabit these areas }{ }^{7} \text {. }\end{array}$ & $\begin{array}{l}\text { Barnett et al. } \\
\text { (unpublished data) } \\
7 \text { [41] }\end{array}$ \\
\hline $\begin{array}{l}\text { Occasionally, Selenicereus wittii } \\
\text { (Cactaceae) was seen, adpressed to the } \\
\text { main trunk, but only above the } \\
\text { highest water-mark. } \\
\text { The water-dispersed orchid Galeandra } \\
\text { devoniana M.R. Schomb. ex Lindl was } \\
\text { also quite common on smaller } \\
\text { specimens whose canopies were } \\
\text { inundated annually. } \\
\text { More shaded specimens had colonies } \\
\text { of Codonanthopsis crassifolia (H. Focke) } \\
\text { Chautems \& M. Perret (Gesneriaceae), } \\
\text { a creeping herb }{ }^{8} \text {. }\end{array}$ & $\begin{array}{l}\text { Selenicereus wittii is reported to be pollinated by } \\
\text { Amphimoena and Cocytius hawkmoths }{ }^{9} \text {, but no } \\
\text { flowering individuals were found for confirmatory } \\
\text { observation. } \\
\text { Euglossine bees were seen visiting the flowers of } G \text {. } \\
\text { devoniana, these are the putative pollinator of the } \\
\text { species }{ }^{10} \text {. } \\
\text { Colonies of C. crassifolia are obligatly associated with } \\
\text { colonies of Crematogaster longispina (Formicidae) }{ }^{11} \text {, } \\
\text { in whose nests they are rooted. Leaves were eaten by } \\
\text { C. ouakary (who would rip of a part of the plant and } \\
\text { eat it at a distance to avoid the ants) }{ }^{12} \text {. Members of } \\
\text { the genus are pollinated by small bees }{ }^{13} \text { - this was } \\
\text { confirmed by field observation, though taxa could } \\
\text { not be captured for identification. }\end{array}$ & $\begin{array}{l}8[42,43] \\
9[44] \\
10[45] \\
11[46] \\
12[12] \\
{ }^{13}[47]\end{array}$ \\
\hline $\begin{array}{l}\text { Phoradendron poeppigii Van Tiegh.) } \\
\text { Kuijt (Santalaceae) }\end{array}$ & $\begin{array}{l}\text { Individuals of this mistletoe species were seen } \\
\text { occasionally on E. tenuifolia trees. Immature } \\
\text { inforescences were removed and eaten by C. ouakary. } \\
\text { Euphonias and other small birds removed fruits. }\end{array}$ & [12] \\
\hline $\begin{array}{l}\text { Root parasites } \\
\text { Helosis cayannensis (Sw.) Spreng. } \\
\text { (Balenophoraceae) }\end{array}$ & $\begin{array}{l}\text { When igapó was unflooded inflorescences and } \\
\text { above-ground stypes of these obligate, but non-host } \\
\text { specific, root parasites were seen close to E. tenuifolia } \\
\text { trunks and exposed roots }{ }^{14} \text {. Inflorescences were } \\
\text { seen being visited by small flies (Tachninidae). These } \\
\text { are considered the main pollinator in this genus }{ }^{15} \text {, } \\
\text { though weevils of the subtribe Oxycorynina (Belidae: } \\
\text { Oxycoryninae), which are only found in association } \\
\text { with Baleophoraceae, may also be involved }{ }^{16} \text {. }\end{array}$ & $\begin{array}{l}14[48] \\
15 \\
16[49] \\
{[50]}\end{array}$ \\
\hline
\end{tabular}

Varying levels of inundation tolerance lead to marked banding-like zonation in the species composition of the igapó tree assemblage [51]. Of these, E. tenuifolia is one of the most highly adapted to prolonged inundation [52]. Such tolerance means it can be found throughout the igapó forest [51], and it may form near-monodominant stands (macacaricurizais) in areas where inundation is too prolonged for other species to survive [53]. The rigors of life in such a challenging environment mean that individuals grow very slowly (1.5-1.7 mm per year), although for extended periods (400-800 years [ 54 ]). Phenology is strongly linked to the seasonal inundation pulse in igapó [55], starting as the water level drops, continuing through the brief period when the igapó forest floor dries up, and until the start of the new flooding season $[31,56]$. Individuals may reach $18 \mathrm{~m}$ in height, and have canopies with surface areas of up to $29 \mathrm{~m}^{2}$, and up to 106 inflorescences per canopy simultaneously [12]. Mass of seeds produced per year is substantial, with means of $55 \mathrm{~g}$ per $\mathrm{m}^{2}$ of canopy, and $5798 \mathrm{~g}$ per plant [12]. However, while collectively the fruit and flowers of the species are available every year, it is rare for individual plants to flower abundantly in two sequential years (AA Barnett and W Souza Silva, unpublished data). Thus, the general pattern is a high-yield year followed by a low-yield year. While this is not biennially in the strictest sense, it is such a strongly marked alternate year pattern, that we believe it can functionally be treated as such. 
In the genus Eschweilera, flowers are strongly zygomorphic and heterantheric. Flowers are large, robust and fleshy, with the infertile stamens on one side of the androecium fused and form a hood covering the ovary (Figure 1B), within which lies the source of nectar. Below lies a staminodal ring which contains anthers with fertile pollen $[57,58]$. The floral biology of E. tenuifolia has only been studied previously in terms of phenology [56]. However, studies of other members of the genus (E. bogotensis R.Knuth. [59]; E. decolorens [58]; E. garagarae Pittier [60]; E. longipes Miers [58]; E. nana [O.Berg] Miers [61]) have reported the presence of nectar at the end of the coiled section of the non-differentiated tissue in the androecial hood. This nectar is accessible once a pollinating bee forces open the hood. Such bees usually land on top of the androcial hood, then invert their bodies and, in this sternotribic position, push themselves into the gap between the basal ring and androecial hood. They then move in further to reach the nectar, receiving pollen from the fertile anthers of the basal ring in the process [62]. Together, the size and weight of the hood greatly reduce ingress by smaller-bodied nectar and pollen thieves [63]. Members of the Xylocopine genus Xylocopa and the Euglossine genus Eulaema are known pollinators for Eschweilera (e.g., E. decolorans and E. longipes [58]; E. ovata [64]; E. nana [65]). Members of the Meliponin stingless bee genera Melipona and Scaptotrigona remove pollen from E. tenuifolia [32]. However, many meliponines are pollen thieves [66,67], including of Lecythidaceae [68], so it is not yet certain whether they are true and effective pollinators. The flowers are the focus of a complex interaction between xylocopid bees and golden-backed uacari monkeys (Cacajao ouakary), where the presence of the former appears to deter the latter from eating E. tenuifolia flowers (AA Barnett, unpublished data). Although some members of the closely-related [69] genus Lecythis are night-pollinated (e.g., Lecythis poiteaui O. Berg, principally pollinated by bats, but also visited by bees and moths [57,70]), all known members of the genus Eschweilera are day-pollinated [2,65].

Fruit in all Lecythidaceae are in the form of a lidded pyxidium, which may or may not be dehiscent [71] (Figure 2) Such fruits are often large and with a highly sclerified pericarp. In addition, levels of seed set in the genus appear to be very low (1.48\% for E. bogotensis [59]; 0.0036\% for E. nana [65]), and this is also true for many members of the family. It has been suggested that the low level of seed set is due to soil nutrient poverty [72] and energetic limitation caused by investment in such energetically-demanding fruit [59].

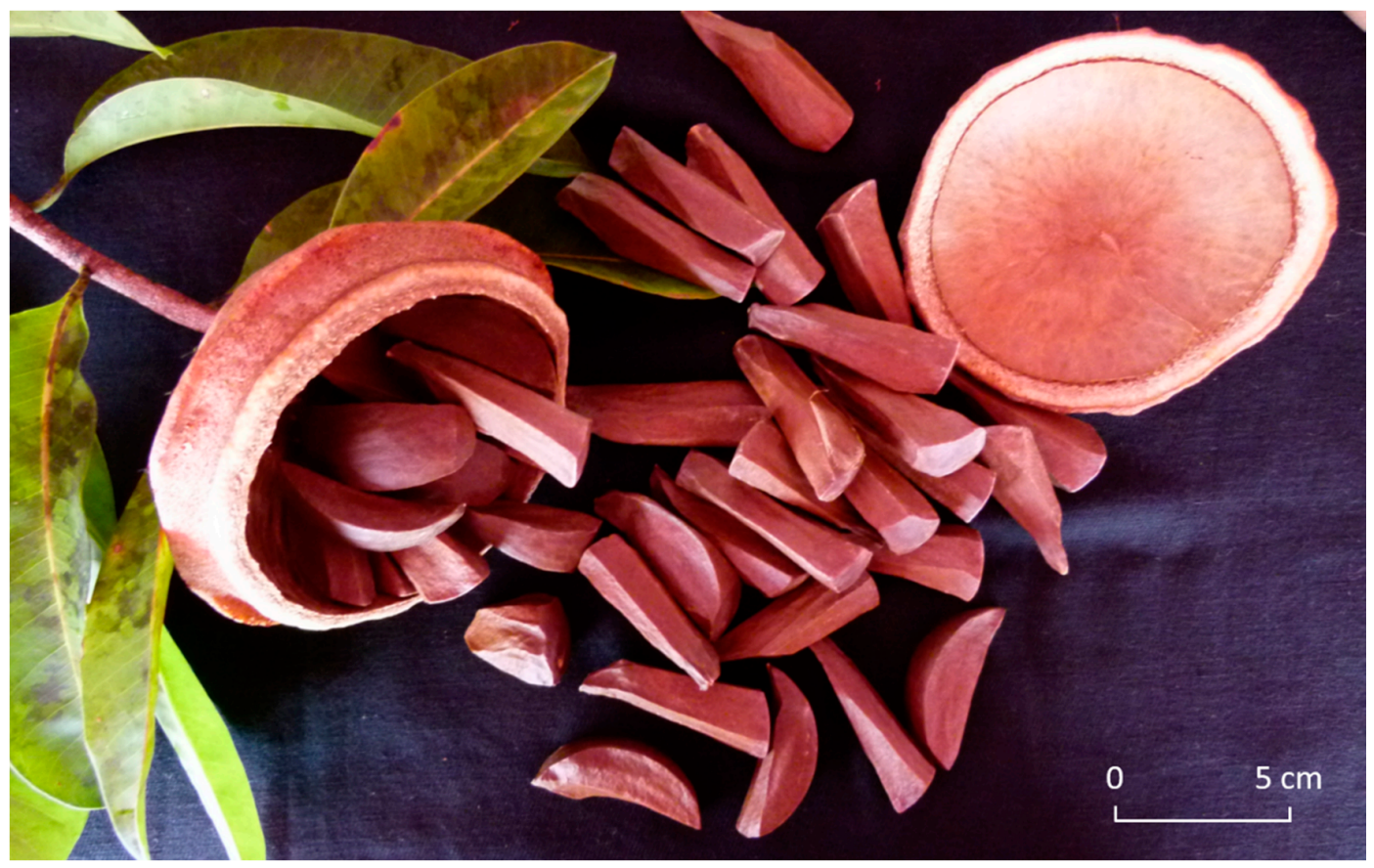

Figure 2. Mature pyxidium of Eschweilera tenuifolia, showing multiple seeds and dehiscent cap. Photo: Naara Ferreira da Silva. 
However, despite the numerical and ecological importance of the species in igapó, phenology of E. tenuifolia has been the subject of only one focal study, conducted by Maia [31] (see also Maia and Peidade [56]). This 17 month study showed that E. tenuifolia follows a leaf drop/leaf flush/flowering pattern (one of the three phenological patterns identified for Lecythidaceae by Mori and Prance [3]), and had the flowering form termed "steady-state flowering" by Gentry [73]. Maia [31] also found both leaf and flower production to be strongly linked to the annual flood pulse, with an annual leaf flush in August, and flower production extending across five months (September through January) during the ebb, lowest water, and flooding periods in igapó. The species was classified as deciduous ("bare of leaves for at least three weeks") by Parolin et al. [74]. The only other phenological study of an igapó member of the genus, E. parviflora, reported a similar temporal patterning: the timing was offset depending on the extent of inundation [75]. However, both studies [31,75] left open several key questions regarding the floral biology of Eschweilera.

Accordingly, we undertook a study of the floral ontogeny, the extent of insect predation of developing flower buds, and the diel cycle of nectar production in E. tenuifolia, quantifying flower size and weight and speed of development, to test the following predictions:

(1) Insect predation of E. tenuifolia flower buds and flowers will be high (operationally defined as over $50 \%$ of buds).

(2) High levels of bud and flower insect infestation will result in low flower:fruit ratios.

(3) Visitation of anthers by pollen predators will occur only once flowers have opened and access is thus facilitated.

(4) Nectar production will occur during daylight hours, and nectar characteristics will meet the criteria for bee-pollinated plants.

\section{Materials and Methods}

\subsection{Study Habitat: Igapó}

In igapó, inundations may reach $7 \mathrm{~m}$ and last for up to 10 months (Prance [76]). Igapó is characterized by a comparatively low per-hectare tree species richness (approximately 60/ha [52], compared to 120-200/ha in neighboring never-flooded forests [77], and a flowering and fruiting phenology that is linked to the annual peaks in river water levels [78]. Because of the low-sediment content of their waters, the floodplains of blackwater rivers are not extensive, rarely exceeding $200 \mathrm{~m}$ in width [79]. However, differences in inclination are sufficient to generate differences in inundation duration across this distance that last from 1 to 10 months. Differences in flood tolerance mean tree species have banded horizontal distributions within the igapó, as well as vertically on hummocks (borokotoh) within it [51].

\subsection{Study Site}

Jaú National Park $\left(1^{\circ} 53^{\prime} 15^{\prime \prime} \mathrm{S}, 61^{\circ} 41^{\prime} 25^{\prime \prime} \mathrm{W}\right)$ is a 2.2 million ha protected area that forms part of the 6 million ha Central Amazonian Ecological Complex [80]. It is located on the south bank of the Rio Negro, some $230 \mathrm{~km}$ upstream from Manaus, the capital city of Amazonas State, Brazil (Figure 3). Regional climate is typical of that for the central Amazon Basin, with seasons defined by rainfall and river flooding. Flooding is highest during June and July, when floodwaters can reach 6-10 m. Average rainfall varies between months, being $1750 \mathrm{~mm}$ between July and September and $2500 \mathrm{~mm}$ from December to April. In May-June and October-November, there is usually little rain [12]. The predominant habitat in Jaú National Park (JNP) is never-flooded, lowland tropical forest (terra firme: approximately $80 \%$ of the park), followed by seasonally-inundated river-margin forest (igapó: $12 \%$ of the park), white sand vegetation (campina: 4\%), and palm and aroid swamps (buritizal and aningal, respectively: $3 \%$ of the park [51]). The human population does not exceed 1000 people and human-modified areas cover less than $0.1 \%$ of the park surface. Additional information on the vegetation at JNP can be found in Ferreira and Prance [77] and Vicentini [81]. 


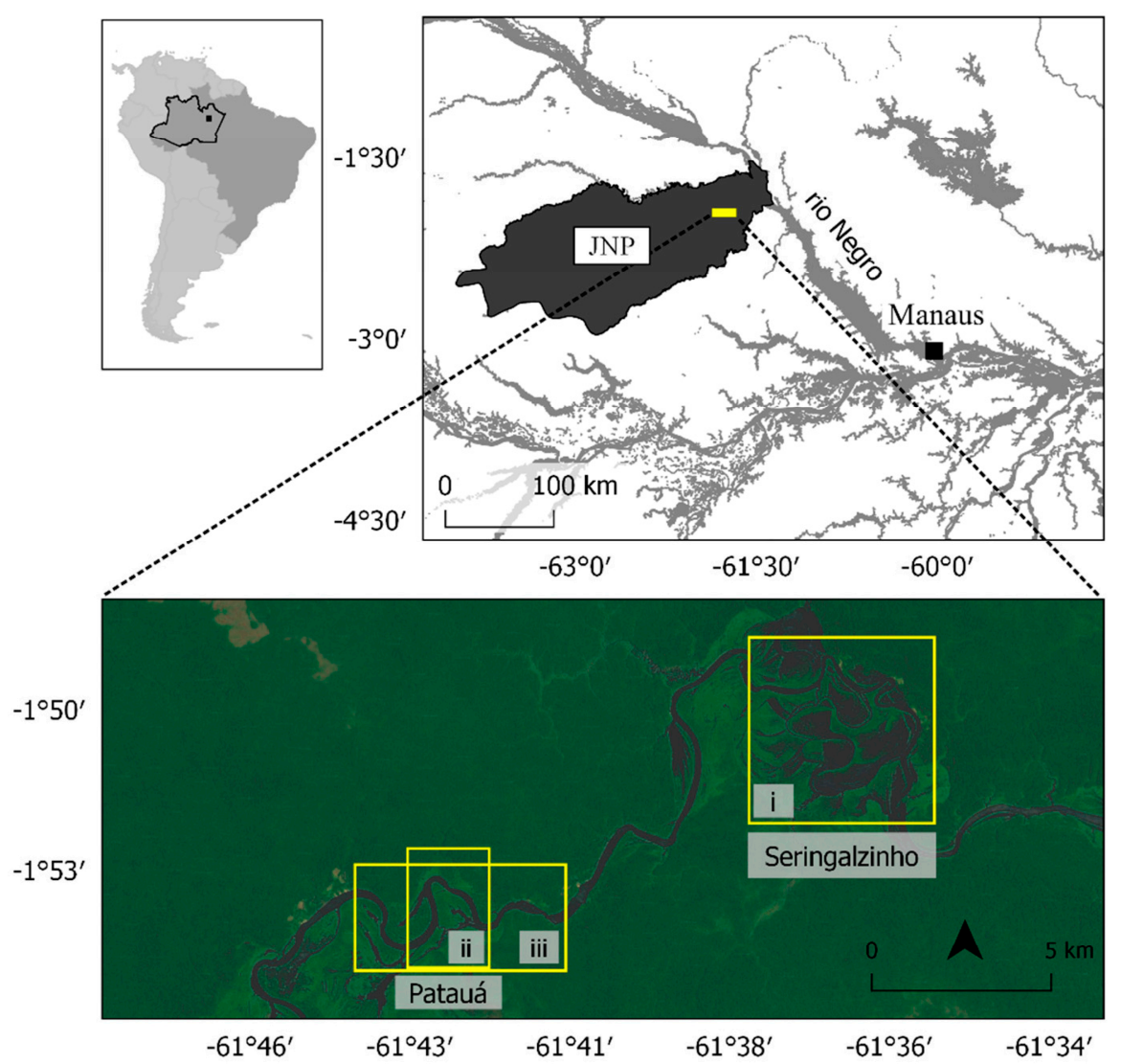

Figure 3. Map, showing location of Jaú National Park (JNP), within Brazilian Amazonia showing study locations within Jaú National Park, central Brazilian Amazonia, based around the villages at Patúa and Seringalzinho. For descriptions of sites i-iii, see Table 3. Cartography: Natalia Kinap.

Table 3. Type of sampling effort and its spatial and temporal distribution.

\begin{tabular}{|c|c|c|c|c|}
\hline $\begin{array}{c}\text { Study Area } \\
\text { (See Map, Figure 4) }\end{array}$ & Study Type & $\begin{array}{c}\text { Prediction } \\
\text { Associated with }\end{array}$ & Year(s) & $\begin{array}{l}\text { Number of Individual } \\
\text { Trees Sampled }\end{array}$ \\
\hline $\begin{array}{c}\mathrm{i} \\
\text { (Seringalzinho) }\end{array}$ & $\begin{array}{l}\text { Preliminary data on } \\
\text { flower ontogeny and } \\
\text { timing of nectar yields }\end{array}$ & 4 & 1999 & $\begin{array}{l}12 \text { (outside the 2006-2008 } \\
\text { phenology plots) }\end{array}$ \\
\hline $\begin{array}{c}\text { ii } \\
\text { (Patuá) }\end{array}$ & $\begin{array}{l}\text { Number of } \\
\text { inflorescences } \\
\text { per canopy }\end{array}$ & $\begin{array}{l}\text { X (supplementary } \\
\text { data) }\end{array}$ & 2006-2008 & $\begin{array}{l}\text { Counted for all } 134 \text { E. tenuifolia } \\
\text { trees (of } 137 \text { present and above } \\
10 \mathrm{~cm} \mathrm{DBH})^{1} \text { that flowered } \\
\text { in } 2007\end{array}$ \\
\hline $\begin{array}{c}\text { ii } \\
\text { (Patuá) }\end{array}$ & $\begin{array}{l}\text { Survivorship of flower } \\
\text { buds to button stage of } \\
\text { fruit production }\end{array}$ & 2 & 2006-2008 & $\begin{array}{l}\text { Marked buds from the } 130 \\
\text { trees in the phenological study } \\
\text { plots that produced fruit }\end{array}$ \\
\hline $\begin{array}{l}\text { ii, iii } \\
\text { (Patuá) }\end{array}$ & $\begin{array}{l}\text { Collection of aborted } \\
\text { buds and flowers }\end{array}$ & 2 & 2006-2008 & $\begin{array}{c}\text { No specific trees involved; } \\
\text { material collected ad libidum } \\
\text { when encountered floating on } \\
\text { water surface. }\end{array}$ \\
\hline $\begin{array}{c}\text { iii } \\
\text { (Patuá) }\end{array}$ & $\begin{array}{l}\text { Analysis of the extent } \\
\text { of invertebrate } \\
\text { infestation of flowers } \\
\text { and flower buds }\end{array}$ & 1,3 & 2006-2008 & $\begin{array}{l}396 \text { buds and } 200 \text { flowers from } \\
11 \text { trees outside the phenology } \\
\text { study plots }\end{array}$ \\
\hline
\end{tabular}

\footnotetext{
${ }^{1}:$ DBH $=$ Diameter at Breast Height.
} 


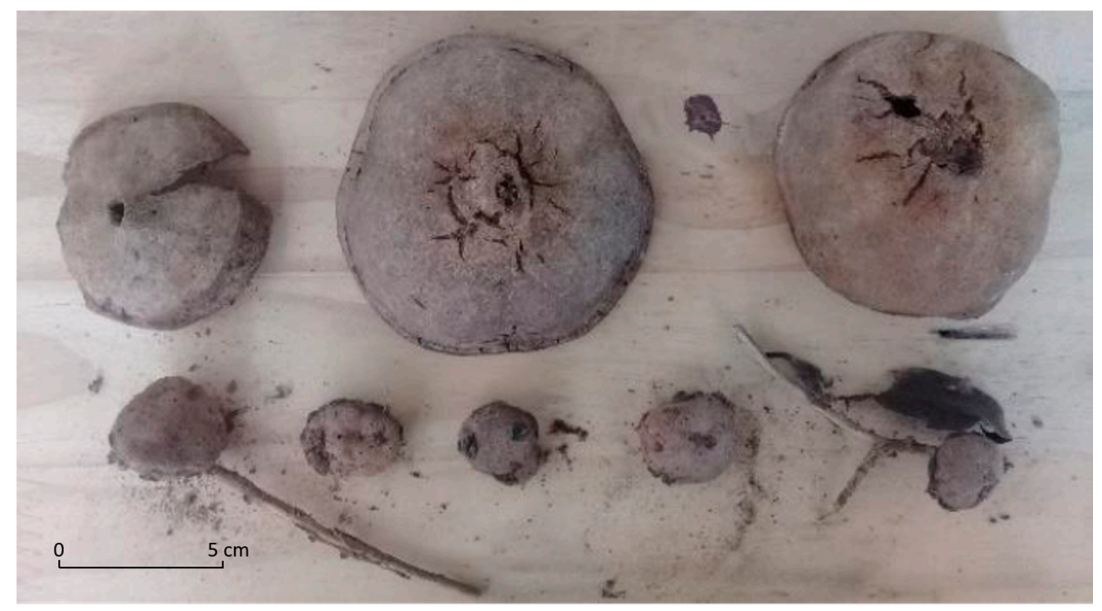

Figure 4. Eschweilera tenuifolia fruits-Mature pyxidia (above), and immature "button stage" pyxidia (below). Photo: Adrian Barnett.

Within JNP National Park, initial studies were conducted during visits to the Seringalzinho region (1999) and Patuá (2000) regions (see [13,21,82-84]). The main study took place between October 2006 and April 2008, as part of a broader study of golden-backed uacari (C. ouakary) ecology $[30,85,86]$. Follow-up data were collected during a return visit to Seringalzinho in 2015 (for all study locations, see Figure 3.)

\subsection{Field Measures}

Data were collected from three areas within the park: (i) a macacaricuizal near the village of Seringalzinho; (ii) the area near the village of Patuá bounded by six 0.25 ha plots used to monitor igapó phenology during the 2006-2008 study; (iii) the remainder of the 2000 ha area used to study the ecology of the golden-backed uacari in 2006-2008 [12,51,87] (Figure 3; Table 3). In total, data were gathered from 194 individual E. tenuifolia trees (originally $\mathrm{N}=197$, but three trees were excluded when they did not flower). For clarity, the distribution of sampling effort is shown in Table 3, with the locations of each study shown in Figure 3).

To test predictions 1-4, we implemented the following field techniques, for which data were collected from paddled wooden canoes during ecological field studies of uacari monkeys (see [88] for details on overall field methods).

Prediction 1-Insect predation of E. tenuifolia flower buds and flowers will be high. A total of 200 open E. tenuifolia flowers and 396 buds were removed from a total of 11 E. tenuifolia trees that were not used in any other part of the study. Buds and flowers were numbered, stored in lidded containers, and then processed within two hours at the field station lab. Buds and flowers were then measured, graded for size, and weighed in units of 10 similar-sized units using an electronic balance (Salter-1250). All were examined for indications of the presence of invertebrates (larvae of Coleoptera, Diptera, Lepidoptera; imagos of thrips (Order Thysanoptera), aphids and small beetles such as staphylinids, plus mites), or their signs (burrows, emergence holes, frass, discoloration). Thrips were identified using characters in Mound [89]. To calculate mean weights of contained material, plant material was reweighed after invertebrates were removed (reliable measures of resident insect mass at the individual bud or flowers level was not adopted, due to the $0.1 \mathrm{~g}$ sensitivity of the balance).

To analyze insect content, flowers were individually dissected with a scalpel, and encountered insects removed. All collected specimens were identified to class, then stored in $70 \%$ ethanol. For comparative analysis, buds were divided into four operational size-based classes: stage 1 (S1): small buds, maximum diameter $4 \mathrm{~mm}$; stage 2: medium 4-8 mm; stage 3: medium-large buds, 8-10 $\mathrm{mm}$; and stage 4: large buds $12 \mathrm{~mm}$ and above, with petals just beginning to unfurl. The sequence was completed by opened flowers (stage 5 ). 
When retrieving infesting insects, the extent of damage made by burrows and feeding activity was estimated by eye into five categories: no (obvious) damage; light (obvious damage to 25\% of androecium); medium (obvious damage to 25 to $50 \%$ of androecium); medium-heavy (obvious damage to 50 to $75 \%$ of androecium); and heavy (obvious damage to more than $75 \%$ of androecium).

Prediction 2-The high levels of bud and flower insect infestation will result in low flower: fruit ratios. To track fruit development to the button stage of pyxidial growth (Figure 4), individual inflorescences on trees in the phenology study plots were marked on the peduncle with a number written in waterproof ink (initial attempts to use flagging tape or fine cords for marking, as used in several Bertholletia studies and by Krause [64] for E. ovata, were not successful due to squirrels removing the items for use as nesting material). This pyxidial development stage was chosen since it is not one consumed by the major fruit predators of E. tenuifolia, macaws (Ara spp.), and the primate C. ouakary $[12,13]$. Since it was possible that, once a flower was pollinated, others in an inflorescence would be aborted or, resources selectively diverted at some point in the maturation process to one fruit on an inflorescence, a single flower was marked on 5 inflorescences on each of the 134 trees that produced flowers in 137 of the phenology study plots, for a total of 670 flowers. Progress was tracked during monthly phenology recording visits. In addition, all encountered fallen buds and flowers were collected when encountered. If both the stem and basal plate of the pedicel of a fallen bud was intact, that bud or flower was considered to have been aborted and was then analyzed by the extent of internal damage, as categorized above.

Prediction 3-Visitation of anthers by thrips and other invertebrate pollen predators will occur only once flowers had opened and access was facilitated. Small invertebrates (thrips, mites, and other taxa) were extracted from the surface of the infertile anthers with a small paintbrush, counted, and stored in alcohol-glycerin-acetic acid, following Lewis [90]. This extraction was performed for both flower buds and open flowers.

Prediction 4-Nectar production will occur during daylight hours, and will be constant across the production period. In 1999, a sample of 360 undamaged flowers was used, with 10 sampled at hourly intervals from 06.00 to $18.00 \mathrm{~h}$. We used three sets of 120 flowers per day, with a different set of 120 flowers from a different set of 12 trees on each of three successive days, to avoid any possible responses by trees to flower removal during sampling). To avoid any effects that flower damage during sampling might have on nectar production, each flower was sampled just once: it was removed from the tree and nectar accessed following a longitudinal cut across along the androecium hood [64]. Nectar sugar concentration was measured with a Brix refractometer [91], and volume production estimated with a graduated $5 \mu \mathrm{L}$ micropipette and calipers [92,93]. In addition, nocturnal nectar production in E. tenuifolia flowers was assayed with sampling at 22.00 and $00.00 \mathrm{~h}$ in 1999 , and at 02.00 and $04.00 \mathrm{~h}$ in 2000. In 1999, 16 flowers from three trees (3, 6, and 7 flowers each) were sampled at $22.00 \mathrm{~h}$, and 11 from a single tree at $00.00 \mathrm{~h}$. In 2000, 9 and 17 flowers were sampled from two individual trees, at 02.00 and $04.00 \mathrm{~h}$, respectively. These trees were selected from those used for sampling diurnal nectar volumes.

\subsection{Statistical Analysis}

Regression analysis was used to test for a relationship between the number of inflorescences per crown and crown size, and between the number of inflorescences per crown and diameter at breast height (DBH).

A chi-square test was used to test for a difference between the proportion of buds and of open flowers that were infested by invertebrates. This was performed both for each bud development category, and for all bud categories combined. A Kruskal-Wallis test was used to test for differences in insect mass between buds and the open flowers. In both infestation rates and insect mass, comparisons were made between flowers and each bud development category (stages 1-4) separately, and then for all bud categories combined. A Mann-Whitney $U$ test was then used to test for differences between buds and flowers in the percentile of the plant material (bud or flower) that these total insect masses 
represented. Because of the possibility that insect larvae would enclose before the flower opened, a Mann-Whitney $\mathrm{U}$ was used to test whether there were differences in infestation rates between stage 3 buds and flowers and, separately, between stage 4 buds and flowers. A chi-square test was used to test for differences in infestation rates across the four bud development stages, stage 1 to stage 4 .

Mann-Whitney $U$ tests were used to test for a difference in infestation rates between open flowers and buds (with the smallest bud class excluded); a difference in insect mass between buds and open flowers (all development stages combined); and a difference in insect mass between buds (in stages 3 and 4) and open flowers. Chi-squared tests were used to test for differences in the percentage of pollen predators in buds versus flowers; a difference in damage rates between aborted and non-aborted buds (all developmental stages combined); a difference in damage rates between aborted and non-aborted buds within each of the four size classes of buds; and a difference in damage rates between aborted and non-aborted flowers.

Lastly, the regularity of nectar production was analyzed with a Mann-Whitney U test by comparing both the nectar volumes and concentrations produced for hourly diel samples. We then ran a regression to test whether nectar volume and nectar concentration (separate regressions) increased linearly from early morning to afternoon. All statistical analyses were conducted using SPSS 25.0.

\section{Results}

\subsection{Floral Characteristics}

Eschweilera tenuifolia flowers occurred in racemose inflorescences towards the ends of branches, and contained between 5 and 18 flower buds (mean \pm SD: $11.04 \pm 2.83, \mathrm{~N}=100$ ). The number of inflorescences per tree varied greatly ( 0 to 53 in 2007, mean \pm SD: $27.49 \pm 15.52, \mathrm{~N}=134$ trees), and showed little relation to tree canopy size $\left(\mathrm{r}^{2}=0.6841, p=0.00096\right.$ for $2007 \mathrm{r}^{2}=0.7047, p=0.584$ for 2008, $\mathrm{N}=15)$ or DBH $\left(\mathrm{r}^{2}=0.5979, p=0.002\right.$ for 2007; $\mathrm{r}^{2}=0.5359, p=0.565$ for $\left.2008, \mathrm{~N}=15\right)$ (Table 4; Figure 5). Generally, only one flower per inflorescence was open at a time: of 100 inflorescences, 82 had one, five had two, and three had three flowers open simultaneously. The number of inflorescences was also not consistent for individual trees between years (Table 4; Figure 5). Of the 12 trees for which data were available in both years, 11 had more inflorescences in the first year, showing a mean drop of $83.2 \% \mathrm{SD} \pm 6.1$. This is consistent with strong biennial variation in reproductive investment (discussed below).

Table 4. Sequential year inflorescence number, diameter at breast height (DBH) and canopy surface area for Eschweilera tenuifolia.

\begin{tabular}{|c|c|c|c|c|c|}
\hline Tree ID & $\begin{array}{l}\text { DBH } \\
(\mathrm{cm})^{1}\end{array}$ & $\begin{array}{l}\text { Canopy (Length } \\
\times \text { Height, in } \mathrm{m})\end{array}$ & $\begin{array}{c}\text { Canopy Curved } \\
\text { Surface Area }\left(\mathrm{m}^{2}\right)^{2}\end{array}$ & $\begin{array}{c}\text { Number of } \\
\text { Inflorescences } \\
\text { in 2007/2008 }\end{array}$ & $\begin{array}{c}\text { Percentage } \\
\text { Difference } \\
\text { between Years }\end{array}$ \\
\hline 1 & 114 & $3.5 \times 1.5$ & 19.23 & $46 / 13$ & -71.7 \\
\hline 2 & 78 & $2.8 \times 2.5$ & 12.31 & $5 /-$ & \\
\hline 3 & 75 & $2.6 \times 1.8$ & 10.61 & $29 / 5$ & -82.7 \\
\hline 4 & 86 & $3.0 \times 2.8$ & 14.13 & $38 /-$ & \\
\hline 5 & 48 & $1.8 \times 2.1$ & 5.09 & $17 / 2$ & -88.2 \\
\hline 6 & 66 & $2.6 \times 2.0$ & 10.61 & $31 / 8$ & -74.2 \\
\hline 7 & 53 & $2.7 \times 2.1$ & 11.45 & $28 /-$ & \\
\hline 8 & 101 & $4.1 \times 3.2$ & 26.39 & $47 / 8$ & -82.9 \\
\hline 9 & 94 & $3.5 \times 2.8$ & 19.23 & $37 / 5$ & -86.5 \\
\hline 10 & 57 & $2.4 \times 1.8$ & 9.04 & $2 / 19$ & +850.0 \\
\hline 11 & 68 & $2.7 \times 2.0$ & 13.25 & $31 / 6$ & -80.6 \\
\hline 12 & 81 & $2.7 \times 2.2$ & 13.25 & $34 / 7$ & -79.4 \\
\hline 13 & 74 & $3.1 \times 1.4$ & 15.09 & $32 / 3$ & -90.6 \\
\hline 14 & 86 & $2.8 \times 2.2$ & 12.31 & $24 / 2$ & -91.7 \\
\hline 15 & 105 & $3.8 \times 2.4$ & 21.67 & $53 / 7$ & -86.8 \\
\hline
\end{tabular}

${ }^{1}$ : rounded down when 0.1 to 0.49 ; rounded up when 0.5 to $0.99 ;^{2}$ : calculated as $2 \pi \mathbf{r}^{2}$. 


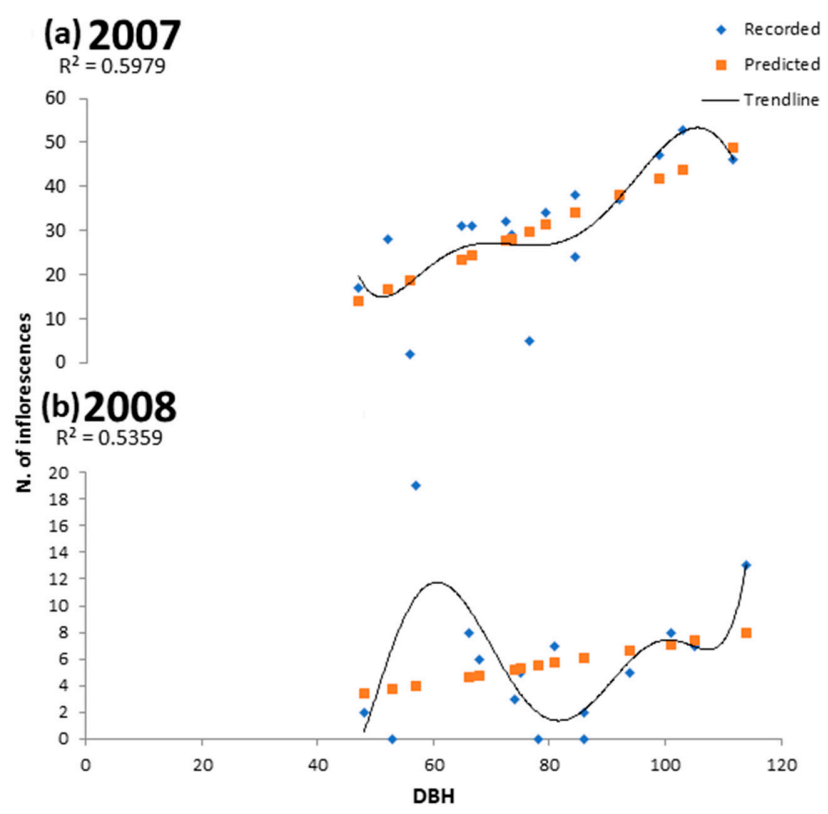

Figure 5. Number of Eschweilera tenufolia inflorescences in sequential years for trees of differing diameter at breast heights (DBHs), Jaú National Park, central Brazilian Amazonia.

The mass of 100 complete, uninfested and fully-open flowers was $627.4 \mathrm{~g}$, and the androecial hoods, when weighed separately, contributed $427.0 \mathrm{~g}(68.1 \%)$ of the mass. Mean flower dimensions were: $5.9 \pm 0.3 \mathrm{~cm}$ from tip to tip of the two largest petals (range: $5.3-6.7 \mathrm{~cm}, \mathrm{~N}=100$ ); $1.9 \pm 0.3 \mathrm{~cm}$ in length (range: $1.2-2.5 \mathrm{~cm}, \mathrm{~N}=100$ ); $1.5 \pm 0.2 \mathrm{~cm}$ in height (range: $1.3-2.4 \mathrm{~cm}, \mathrm{~N}=100$ ); and $1.7 \pm 0.3 \mathrm{~cm}$ (range: $0.8-2.4 \mathrm{~cm}, \mathrm{~N}=100$ ) in width for the androecium.

Inflorescence formation began in September, following leaf flush. However, speed of bud development varied between plants, with some becoming open flowers within 30 days and others taking 60 days or more.

\subsection{Insect Predation}

Infestation intensity: Of the 396 buds and 200 flowers, 58.8 and $73.0 \%$, respectively, contained insect larvae. Within the tissues of 233 infested buds, we found a total 873 larvae from 10 different morphotaxa (3 Coleoptera, 5 Diptera, 2 Lepidoptera: mean no. individuals per bud $( \pm \mathrm{SD}), 3.74 \pm 1.74$, range 1-9; mean no. morphotaxa per bud $( \pm \mathrm{SD}), 2.50 \pm 1.10$, range 1-5). The 146 infested flowers had 394 individuals of four morphotaxa (2 Coleoptera, 1 dipteran, 1 lepidopteran: mean no. individuals per flower $( \pm S D), 2.69 \pm 0.65$, range 1-4; mean no. morphotaxa per flower $( \pm S D), 1.94 \pm 0.80$, range 1-3). These infestation levels of buds and flowers were statistically different for the number of larvae $\left(\chi^{2}=11.50\right.$, df $\left.1, p \leq 0.001\right)$. Mean $( \pm S E)$ numbers of insect morphotaxa on buds and flowers were $2.50 \pm 0.073$ and $1.95 \pm 0.066$ respectively. The number of morphotaxa on buds was significantly greater than on flowers $(\mathrm{t}=-5.27, \mathrm{df}=377, p<0.001)$.

Relative masses of plant/invertebrate material: In terms of comparative masses, the mean value for infested buds weight (all stages) was $5.53 \pm 1.08 \mathrm{~g}$ (range: $4.1-6.65 \mathrm{~g}$ ), with $17.93 \% \pm 10.82$ (range: $7.30-32.00 \%$ ) of this being insect larvae. For infested flowers, mean mass per whole flowers was $5.37 \pm 0.147 \mathrm{~g}$ (range: $5.17-5.65 \mathrm{~g}$ ), with infesting larvae comprising $11.17 \% \pm 2.76$ (range: $5.80-16.30 \%$ ) of a flower's weight. Both proportional and absolute masses of infesting insects changed during flower development, with the greatest values recorded in stage 3, before flowers began opening (stage 4; Figure 6).

Infestation intensity by bud size: Of the buds analyzed, $28.00 \%$ (43 of 150) of the small (stage 1) buds, $80.10 \%$ (98 of 121) of the medium (stage 2) buds, $88.60 \%$ (78 of 88 ) medium-large (stage 3 ) buds, and $37.00 \%$ (14 of 37) large (stage 4) buds were infested (though extents of infestation varied). 
Within these size classes, these differences were significant $\left(\chi^{2}=54.58, \mathrm{df}=3, p<0.001\right)$. However, mean infesting insect mass was significantly lower in flowers than in buds, both overall $(H=19.859$, $p<0.01$ ), and when only large buds (stages 3 and 4 ) were used $(\mathrm{U}=3.706, p<0.001 ; \mathrm{U}=2.24, p=0.025$ : for stages 3 and 4 , respectively). In summary, we found support for the prediction that infestation would be high.

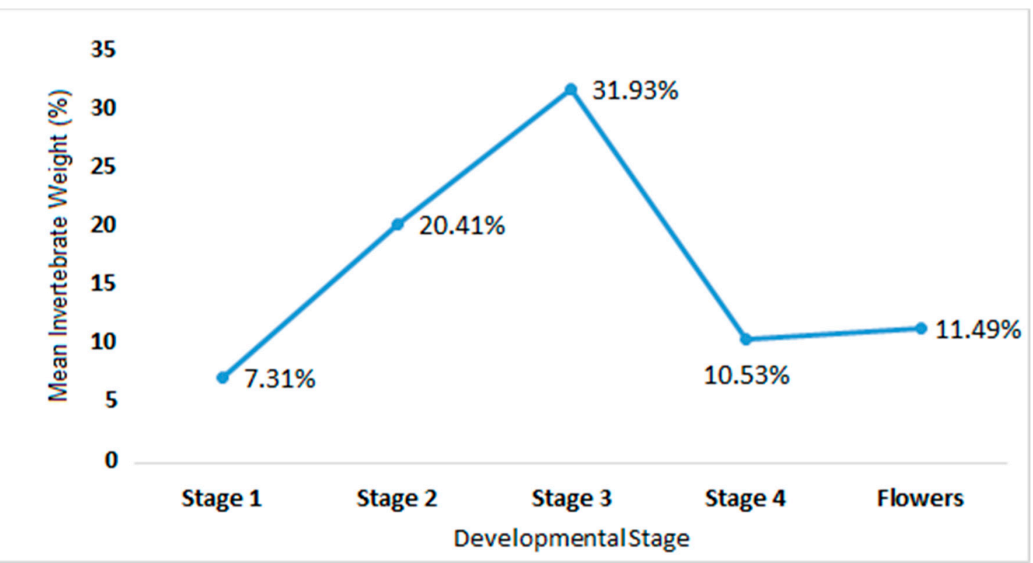

Figure 6. Mean proportional weight of invertebrates in developing buds and flowers of Eschweilera tenuifolia.

\subsection{Flower:Fruit Ratios}

In terms of the extent of damage of aborted and non-aborted buds, a total of 86 aborted buds (stage 1: 27, 31.4\%; stage 2: 10, 11.6\%; stage 3: 15, 17.4\%; stage 4: 34, 39.6\%) and 53 aborted flowers were collected and analyzed. Percentages of damage by damage class (light-heavy) for aborted and unaborted buds by developmental stage (stages 1-4) are given in Table 5. The percentage of aborted and non-aborted flowers by insect damage category is given in Table 5 (as stage 5). Damage level differed across size classes for buds that were aborted $\left(\chi^{2}=526.1, \mathrm{df}=12, p<0.001\right)$, and for buds that remained on the tree $\left(\chi^{2}=124.0, \mathrm{df}=12, p<0.001\right)$. While aborted buds generally had greater levels of damage when larger, there was no clear pattern for buds that remained on the tree; the smallest and the largest two size classes had the greatest percentage of their buds in the category of no obvious damage (Figure 7). In all, when the two lowest damage categories were combined, three of the four size classes for buds remaining on the tree had $90 \%$ or more of their samples in these two categories; the third size class had $75 \%$ of its samples in the two low-to-no damage classes. Comparatively, only the smallest size class of buds that were aborted (stage 1) demonstrated no obvious damage or light damage (Table 5).

Table 5. Degree of damage by infesting invertebrates on aborted and unaborted buds (Stages 1-4), and flowers (Stage 5) of Eschweilera tenuifolia.

\begin{tabular}{|c|c|c|c|c|c|c|}
\hline \multirow[b]{2}{*}{ Size Class (N) } & \multirow[b]{2}{*}{$\begin{array}{c}\mathrm{A}=\text { Aborted } \\
\mathrm{U}=\text { Unaborted } \\
\text { (from Tree) }\end{array}$} & \multicolumn{5}{|c|}{ Damage Category (N, \% of class) } \\
\hline & & $\begin{array}{c}\text { No Obvious } \\
\text { Damage }\end{array}$ & Light & Medium & Medium-Heavy & Heavy \\
\hline Stage 1 (27) & A & $5(18.5 \%)$ & $15(55.5 \%)$ & $7(26.0 \%)$ & $0(0.0 \%)$ & $0(0.0 \%)$ \\
\hline Stage $2(10)$ & A & $0(0.0 \%)$ & $0(0.0 \%)$ & $8(80.0 \%)$ & $2(20.0 \%)$ & $0(0.0 \%)$ \\
\hline Stage $3(15)$ & A & $0(0.0 \%)$ & $0(0.0 \%)$ & $0(0.0 \%)$ & $11(73.0 \%)$ & $4(27.0 \%)$ \\
\hline Stage $4(34)$ & $\mathrm{A}$ & $0(0.0 \%)$ & $0(0.0 \%)$ & $2(5.9 \%)$ & $17(50.0 \%)$ & $15(44.1 \%)$ \\
\hline Stage 1 (150) & $\mathrm{U}$ & $107(71.3 \%)$ & $39(26.0 \%)$ & $4(4.7 \%)$ & $0(0.0 \%)$ & $0(0.0 \%)$ \\
\hline Stage 2 (121) & $\mathrm{U}$ & $23(19.0 \%)$ & $86(71.1 \%)$ & $12(9.9 \%)$ & $0(0.0 \%)$ & $0(0.0 \%)$ \\
\hline Stage $3(88)$ & $\mathrm{U}$ & $10(11.4 \%)$ & $56(63.6 \%)$ & $20(22.7 \%)$ & $2(2.3 \%)$ & $0(0.0 \%)$ \\
\hline Stage 4 (37) & $\mathrm{U}$ & $23(62.2 \%)$ & $10(27.0 \%)$ & $3(8.1 \%)$ & $1(2.7 \%)$ & $0(0.0 \%)$ \\
\hline Stage 5 (53) & $\mathrm{A}$ & $3(5.7 \%)$ & $15(28.3 \%)$ & $26(49.1 \%)$ & $7(13.2 \%)$ & $2(3.8 \%)$ \\
\hline Stage 5 (200) & $\mathrm{U}$ & $54(27.0 \%)$ & $127(63.5 \%)$ & $18(9.0 \%)$ & $1(0.5 \%)$ & $0(0.0 \%)$ \\
\hline
\end{tabular}



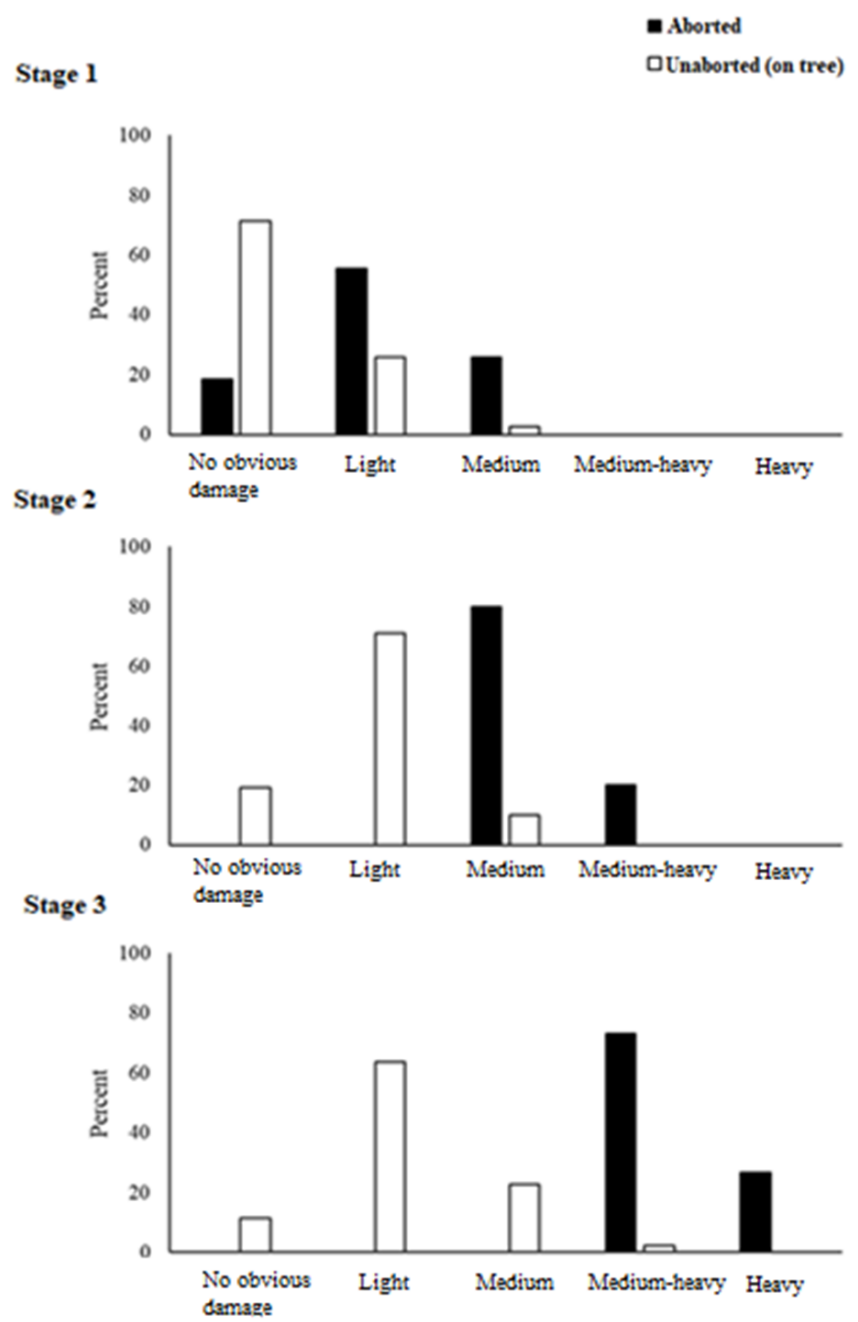

Stage 4

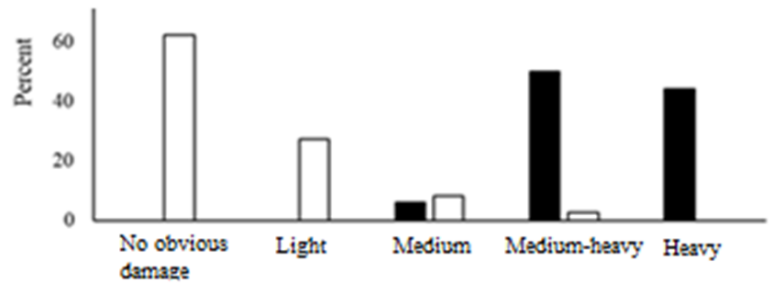

Stage 5

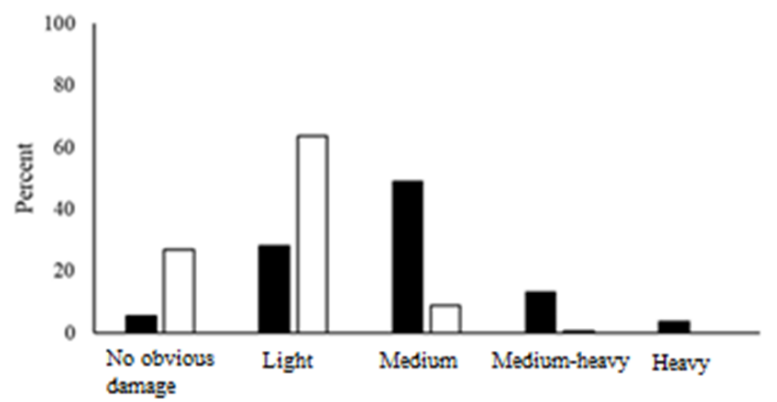

Figure 7. Bud damage percentage for the five developmental stages for fallen (aborted) buds and flowers, and on-tree buds and flowers (unaborted): Eschweilera tenuifolia, Jaú National Park, central Brazilian Amazonia. 
Overall, there was a pronounced difference between the extent of damage to buds that were aborted from the tree (and so were found floating on the water surface) and those that remained on the tree (and were thus considered unaborted) $\left(\chi^{2}=99.2, \mathrm{df}=4, p<0.001\right)$. For example, only $5.8 \%$ of the aborted buds showed no obvious damage, while $41.2 \%$ of the buds on the tree showed no obvious damage (Figure 7). When the aborted buds and those buds that had remained on the tree were compared within each of the four size classes, these differences held for each of the four size classes (stage 1; $\chi^{2}=56.49, \mathrm{df}=4, p<0.001$; stage $2: \chi^{2}=164.76, \mathrm{df}=4, p<0.001 ;$ stage $3: \chi^{2}=191.08, \mathrm{df}=4$, $p<0.001$; and stage $\left.4: \chi^{2}=176.10, \mathrm{df}=4, p<0.001\right)$.

The extent of damage also differed between flowers that had been aborted and flowers that remained on the tree $\left(\chi^{2}=70.26, \mathrm{df}=4, p<0.001\right)$. Only $5.8 \%$ of aborted flowers had no obvious damage, while $27.0 \%$ of the flowers on the tree showed no obvious damage (Figure 7, stage 5). In addition, on some study plants, up to $25 \%$ of flowers had 1 to 3 petals all or partially removed by leaf-cutter bees (Megachilidae).

Of the 134 trees in the study that flowered, 97.01\% $(\mathrm{N}=130)$ produced fruit. However, of these 130 trees, three trees died or suffered tree-fall damage during the study. Of the 635 inflorescences on the remaining 127 trees, $5.83 \%(\mathrm{~N}=37)$ disappeared during the monitoring process. Thus, calculations were based on 598 inflorescences and the single flower monitored on each of these inflorescences. In total, $3.5 \%$ (21 of 598) of marked flowers produced fruits that reached the button stage of development. Since testing for infestation was destructive, it was not possible to say whether flowers that did not produce fruits were infested with insect larvae or not. However, the percentage of aborted stage 3 and stage 4 buds with internal damage levels categorized as 'high', was significantly higher than those remaining on the tree (Figure 7, stage 5). For flowers, significantly more aborted flowers showed damage to anthers than did flowers that were removed from the tree for analysis (Figure 7). Thus, while we cannot offer direct evidence that the flowers that developed into fruits were uninfested, or only lightly infested, and those failed to produce fruits had heavy infestation and were aborted, we believe that this is a reasonable inference from the available data.

\subsection{Pollen Predation}

Thrips, mites, aphids or staphyllinid beetles were present in $1.8 \%(\mathrm{~N}=7)$ of buds, and $49 \%$ $(\mathrm{N}=98)$ of flowers; there was a statistical difference between infestation levels of buds versus flowers $\left(\chi^{2}=201.56, \mathrm{df}=1, p<0.001\right)$. In the flowers, the great majority (not counted, but visually estimated at over $80 \%$ ) were found on the infertile 'fodder pollen' of the adroecial hood. Thrips from two families (Phlaeothripidae and Thripidae) were identified, although 30\% remained unassigned.

\subsection{Nectar Production}

A total of 720 flowers were sampled in daylight and 53 at night. There were strong peaks in nectar production between 06.30 and $10.00 \mathrm{~h}$. Little or no production occurred after $13.00 \mathrm{~h}$ and none between 15.00 and $18.00 \mathrm{~h}$. None of the flowers collected after dark showed any evidence of nectar production (Figure 8). Brix sucrose levels averaged 37.4\% \pm 3.65 (range: 29-44\%, N = 275). With zero values removed, nectar volumes varied between 10 and $560 \mu \mathrm{L}$ (mean 171.7 $\mu \mathrm{L}, \mathrm{SD} \pm 125.2 \mu \mathrm{L}$, $\mathrm{N}=322$ (Figure 9). Temporal variations in both sugar concentration and nectar volume were observed (Figures 8 and 9), with low initial volumes and concentrations very early in the morning, presumably before photosynthetic products were available for mobilization, after which levels largely stabilized until a rapid decline in the early afternoon. There was no recorded nectar production at night (Figure 8). 


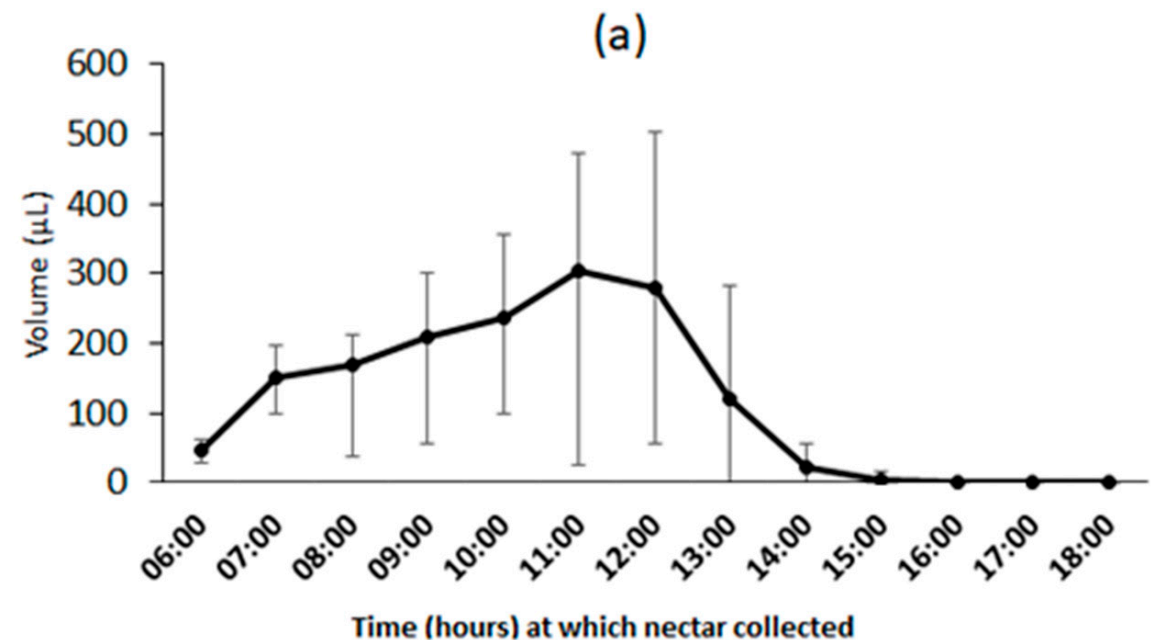

(b)

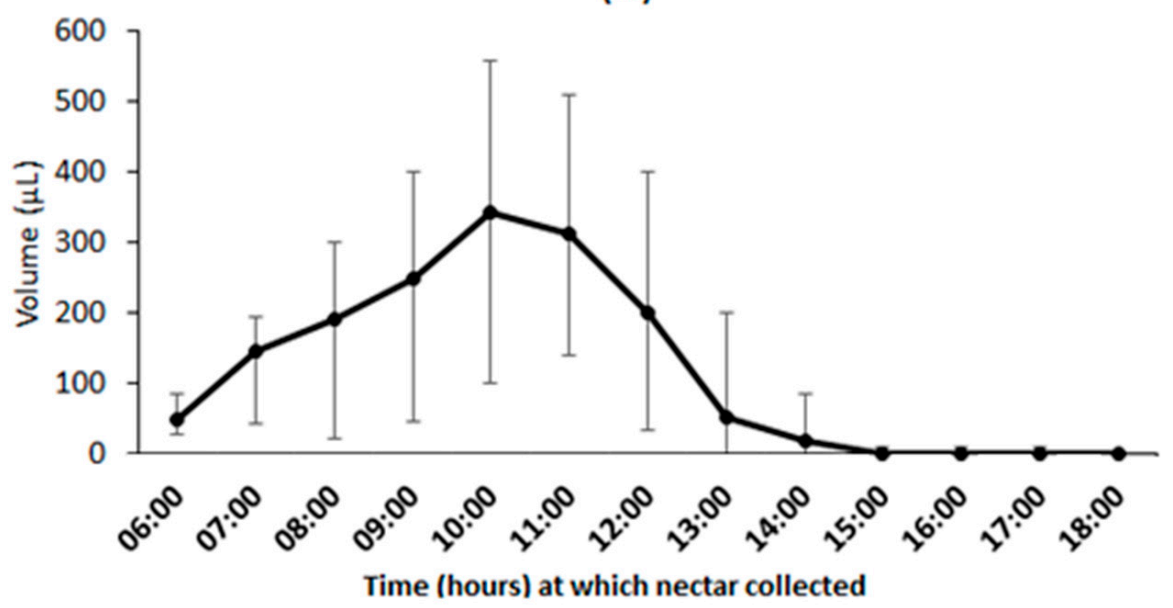

(c)

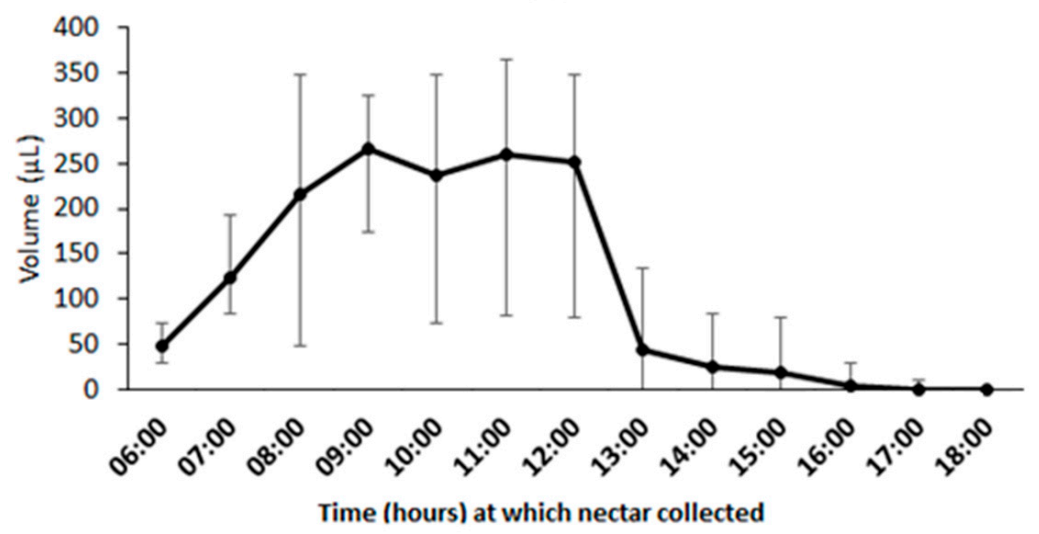

Figure 8. Diel variation in mean $\pm \mathrm{SD}$ nectar volumes for first three days of flowering: $(\mathbf{a})=$ day 1 , (b) = day $2,(\mathbf{c})=$ day 3 . 
(a)

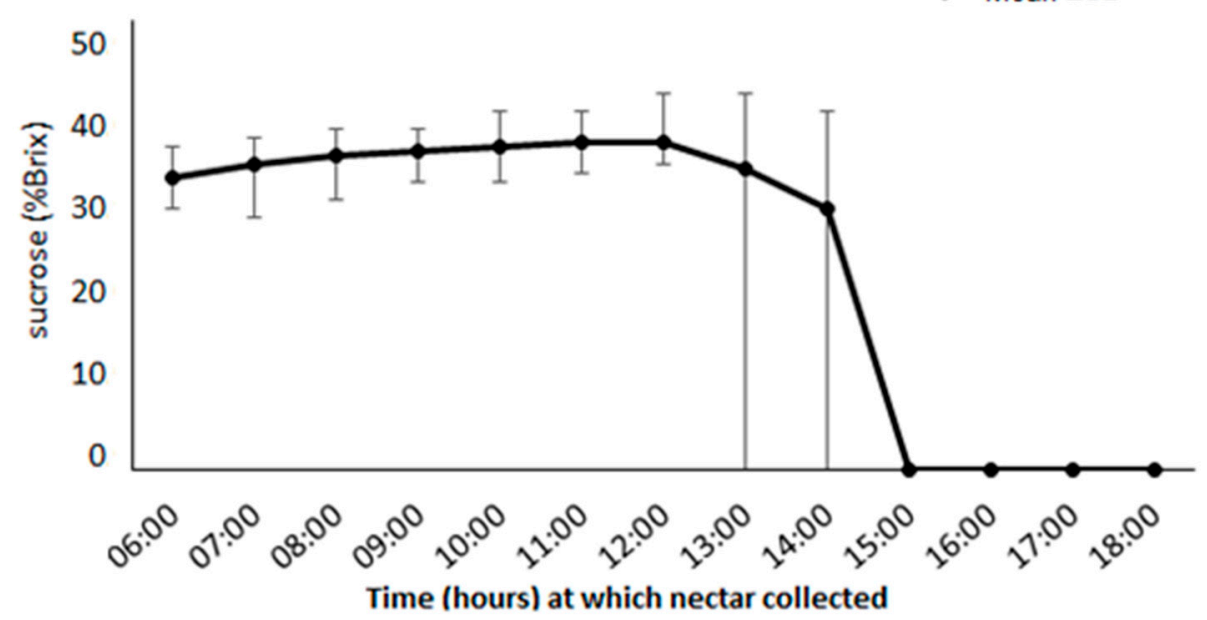

(b)

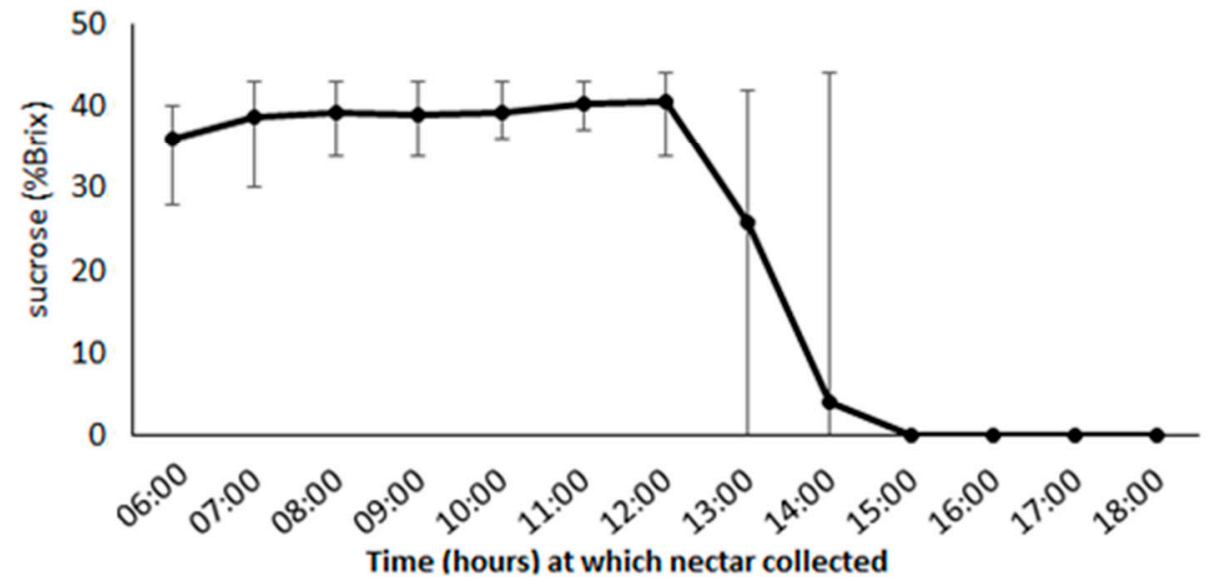

(c)

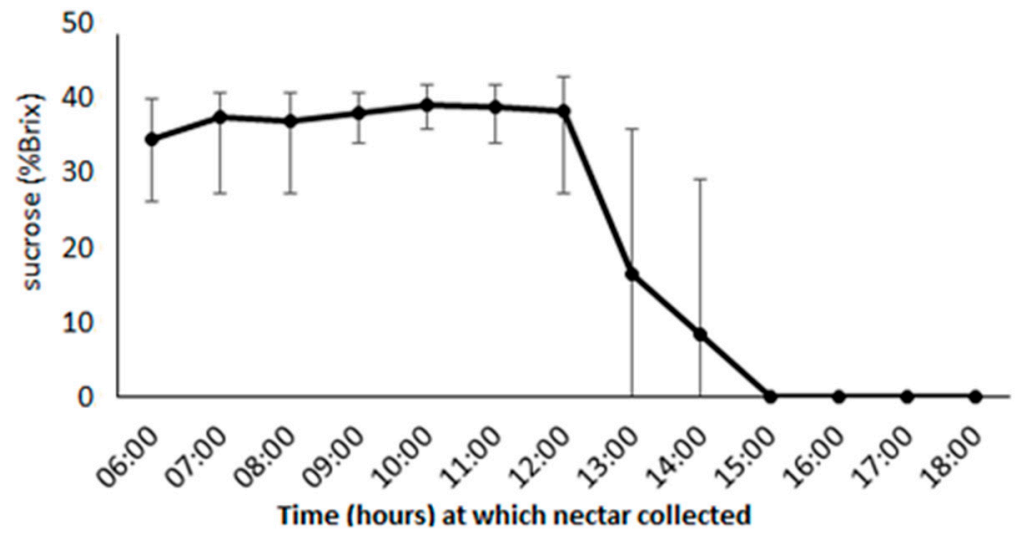

Figure 9. Diel variation in nectar concentrations for first three days of flowering (mean $\pm \mathrm{SD})$ : $(\mathbf{a})=$ day 1 , (b) = day 2 , and $(\mathbf{c})=$ day 3 .

\section{Discussion}

Levels of fruit set in Eschweilera are generally low (e.g., 0.0036\% [65]), and this appears common in the family, having been observed for other genera within the Lecythidaceae, e.g., $0.4 \%$ for Betholletia [72,94] (Couroupita [95]; Lecythis [96,97]). Therefore, it is curious that levels reported in the current study were much higher (21/598: 3.5\%), especially since soil nutrient poverty [59] and energetic limitation [59] have been advanced as explanations for low fruit set in species living in habitats 
that are far less challenging than the igapó inhabited by E. tenuifolia. However, the result may be a methodological artefact, since previous studies did not specify the developmental stages at which study fruits were enumerated. In our study, since we aimed to avoid the impact of predation by vertebrate seed predators during a study of the impact of invertebrate bud predators on fruit set, counting was paused at an early stage in pyxidial development. Though methodologically valid, our methods may have led to higher values being tallied, thereby limiting comparisons with earlier studies, which would have included the later, larger, stages at which vertebrate predation typically occurs. In addition, hand-pollination of E. ovata gave 85\% fruit set [64], suggesting that other factors, such as pre-pollination abortion of flowers, may be involved in the low fruit set values otherwise observed.

Commercial crop reduction is often impacted by insect infestation of flower buds [98-100], and this may also occur in E. tenuifolia. The highest proportion of infested buds was found in stage 3 (medium/large). Stage 4 (large), the stage at which petals would unfurling, had fewer infested buds than the immediately preceding stages. This may be related to the high rate of bud abortion observed prior to flowers opening to attract pollinators. This has been found to occur by other plants as a response to bud infestation [101-104], and it may be common in Lecythidaceae: bud infestation and low rates of fruit set have been noted in previous studies [59,60,65]. Lecythidaceae flowers generally have very well-defined abcissional plates [105], and abortion of insect-infested buds has been recorded in some members of the family (Eschweilera bogotensis [59]; Napoleonaea vogelli Hoolv. [106]). In any case, flower:fruit ratios in Lecythidaceae appear to be low compared to those of other tropical trees, and in the range of values of species where these ratios are considered low (Myristica insipida R.Br. Myristicaceae, 1\% [107]; Grevillea spp., Proteaceae, 0.015-0.096 [108]).

Mean infesting insect mass was significantly lower in the flowers than buds, both when all four bud stages were considered and when only large buds (stages 3 and 4) were used. The proportion of infested buds also dropped dramatically between stages 3 and 4 . From this, the plants appear to be selectively aborting infested buds, a well-known response to infestation [102,109]. The subsequent rise in percentage infestation in flowers is likely due to a second wave of infestation, with either (i) the maturation at the flower stage of many small larvae laid at the bud stage, but not seen or (ii) infestation and rapid growth of larvae in flowers once open. As the larvae of the beetles studied by Udovic [109] require a week to develop in a bud, and bud-infesting moths appear to require a similar minimum [110], option (i) is perhaps the most likely. However, both mechanisms would give a two-phase infestation pattern, so that further work is required to discover which is in operation.

The notable change between stages 3 and 4 in the proportion of the mass of the bud represented by infested insects and by the proportion of buds that were infested indicates that buds grew up to a point (stage 3) and then, if infested, tended to be aborted after this. Thus, flowers that opened were those that were either (i) uninfested or (ii) had insufficient infestation to trigger abortion responses by mother plant (which are generally chemically-mediated and have critical threshold levels [111,112]).

Distribution of damage categories as the buds developed showed likely early abscission of uninfested buds in stage 1 (Figure 7) as a means of reducing on-inflorescence competition between fruits [113], as well as the trend for proportional increases in infestation as buds mature (Figure 7 , stages 2-4). The overall impact of insect damage on bud abortion may be seen in the over-representation of stage 4 , in the sample of aborted buds. Aborted flowers were significantly more heavily infested than flowers on trees. Thus, it appears that infestation of buds and flowers can reduce the number of locations for pollination (and perhaps the number of flowers that have been pollinated that can go on to develop fruits), which, overall, contributes to lower fruit set and reduced flower:fruit ratios. Indeed, as noted by Herrera et al. [114], fruit set is pollen limited in many animal-pollinated plants, so that there may often be more flowers available than can be visited and pollinated by local pollinator populations.

There may be some bias as, when floating, more heavily infested buds and flowers may have been eaten preferentially by fish (many igapó fish using allochthonous materials due to low aquatic system productivity $[115,116])$. While this would only have occurred once igapó was well-flooded, 
it may have caused underestimation of heavily infested categories. Additionally, the damage categories were deliberately broad to guarantee reasonable numbers for statistical analysis. However, as a result, finer patterns may have been obscured. This could be resolved with larger samples and more precise damage percentage categorization. Additionally, it is acknowledged that, in later stages, it is not possible to be certain whether observed damage resulted from recent insect activity, or whether it is the result of smaller-sized activities whose dimensions have grown as the bud expanded. However, either way, if the overall fitness of the organ as a reproductive module is impeded (by herbivory, for example), this may be what determines whether the bud or flower is aborted or not [117,118].

In terms of energy balance, rapid detection and subsequent abscission of infested buds is favorable for the overall reproductive success of an individual plant, as a flower resulting from an infested bud may be inviable due to anther [109] or ovary damage or removal [119]. Further, a flower may not attract pollinators if, as a result of larval action [120,121], lacks nectar or other products that attract pollinators once the infesting larvae have destroyed the nectar-producing glands [122,123]. These, together, can result in the attraction of fewer pollinators and/or setting fewer seeds.

Future studies should investigate if bud infestation has an adaptive component, since having some already infested buds may protect the uninfested buds, by making them (a) the few among many, and so harder to find-possibly triggering search abandonment by egg-laying females via implementation of optimal giving-up time strategies; (b) increasing the chance that, if female invertebrates do lay eggs, that they will deposit on a bud that is already occupied and so not impact currently uninfested buds; (c) reduce the chances attack by parasitoid wasps, since larger, already present, larvae are more likely to be detected and/or encountered by prey-seeking wasps. Alternatively, it may be that insect larvae secrete chemicals that disrupt the plant response systems into responding as though there is no threat ("thinking that all is well" [124]). By virtue of the size and abundance of the flowers, the E. tenuifolia flower/insect system allows investigation of such subtle interactions, and so further investigation is encouraged.

Thrips, small beetles and other potential pollen predators were almost entirely absent from buds. Therefore, we found support for the prediction (prediction 3) that visitation of anthers by pollen predators would occur only once flowers had opened and access was facilitated. Levels of flower infestation by thrips, mites and staphylinid beetles was fairly high (49\%) in the current study. All these invertebrate taxa contain members that are known predators of pollen [125-127]. However, without detailed studies, it is not possible to be certain that this was the case here (though it must be considered very likely). If they were predators, then the higher rates of mite and thrip infestation on the upper, infertile, anthers may indicate that such pollen functions sacrificially, reducing the loss of fertile pollen. However, other studies of Lecythidaceae mention mites and thrips present in and between anthers $[95,128]$, and the relative proportions of distribution between the two anther types may do no more than reflect their relative surface areas. However, it is clear that the buds have very low levels of thrip, mite, aphid and staphylinid infestation, which is likely due to the mechanical difficulty they would face in entering a closed bud unaided, since most species of such pollen predators are phoretic $[129,130]$, and so would be unlikely to colonize a flower until pollinators can visit it. In terms of pollen loss to thrips, while Thripidae includes many pollen feeders, the majority of Phlaeothripidae species are fungus feeders or carnivorous $[89,90]$. Thus, at least a proportion of the thrips present may have been feeding on yeasts, rather than pollen, or the other thrips, mites and aphids inhabiting the flowers at the time.

Petals are one of the many materials used by megachilid bees to line nest brood cells [131]. However, the effect of megachilid bee petal removal on pollinator visitation and pollination success in E. tenuifolia was not investigated in the current study. But, given the well-established influence of flower size these aspects of floral biology [132,133], and flower damage [134,135], it would not be surprising if there were effects to be documented. The system clearly lends itself to experimental manipulation [136], and could be an interesting subject for future study. 
The pattern of sucrose concentration and nectar volume recorded here parallels that recorded for E. nana [65], with rapid rises in levels in the early morning and swift declines in the early afternoon. Neither of these resembles the pattern recorded for E. ovata [64], which showed a distinct midday peak. Purely diurnal pattens of nectar production confirming diurnal pollination, while patterns of nectar production (in both volume and sucrose content), This provided support for the prediction (prediction 4) that nectar production would occur during daylight hours, and would be constant across the production period.

Mean sucrose levels of $37.4 \%$ recorded here are close to those reported for E. coriacea (DC.) S.A. Mori (36\% [137]), E. ovata (36.4\% [64]), and E. nana (30.7\% [65]); all are in line with the 30-40\% concentration considered biomechanically optimal for suction-feeding Euglossine bees [138]. Prance [58] reported that visits by xylocopid bees to Eschweilera trees occurred between 08.30 and 10.00 hrs. Although the data were recorded in terra firme species of Eschweilera, it still matches the patterns we recorded. Indeed, it appears that the timing of nectar production can be remarkably consistent between congeneric species across habitats when, as here, the form of pollinator remains the same [139,140]. Mean nectar volumes recorded here $(171.7 \pm 125.2 \mu \mathrm{L})$ are also similar to those recorded for the similar-sized flowers of E. nana $(196.5 \pm 102.4 \mu \mathrm{L}$ [65]). Values in the current study may be lower due to the presence in the data set of very low values $(10-40 \mu \mathrm{L})$, possibly associated with measurements being conducted immediately after a nectar removal event by a pollinator. If such values below $99 \mu \mathrm{L}$ for days $1-3$ are removed from the 324 records from 06.00 to $14.00(n=114,35.2 \%$ of all records), the mean rises to 241.7, $\mathrm{SD} \pm 97.37$

The duration of flowers (4-5 days) is unusually long for the neotropical Lecythidaceae which, according to Mori and Prance [3] "open their flowers early in the morning and drop their petals and androecia in the same afternoon". However, while E. ovata flowers may also last but a single day [64]), other members of the genus Eschweilera do not follow this pattern, as flowers generally last 2-3 days (E. grandiflora (Aubl.) Sandwith and E. pedicellata (Rich.) S.A. Mori [57]; E. nana [65]); though E. ovata flowers may last but a single day [64]). The extension of individual flower life to 5 days in E. tenuifolia may be a means of maximizing likely reproductive gains in an energy-limited system. This may help explain the higher levels of seed set noted in E. tenuifolia compared to other species. However, this may itself be a compensatory mechanism for the fact that E. tenuifolia is hydrochorous [35], and so may be expected to suffer high levels of seed mortality during dispersal [141-143]. Whether this, itself, is offset with reduced investment in pyxidial wall thickness will be the subject of a future study.

As noted by Janzen [144], direct consumption of flowers can lower seed crop size, but the relationship of flower crop size to seed crop size may not be especially tight. Many plants produce large numbers of flowers only to attract pollinators, and as a plant can perceive the loss of a flower, there may be some compensatory flower production. Nevertheless, the high flower:fruit ratios and large crop volumes of E. tenuifolia are surprising, especially considering how challenging it appears to be for plants to live in igapó [145], particularly in sites where flooding can last for 7 to 8 months, as is the case with E. tenuifolia $[51,146,147]$. However, partial compensation for this stress may be the deployment by E. tenuifolia of a strategy of near-biennial flowering, such that each plant has a heavy flowering year, followed by a light one (AA Barnett and WS da Silva-Carneiro, unpublished). Such a supra-annual flowering also occurs in other igapó tree species, including Aldina latifolia Spruce ex Benth and Cieba pentandra (L.) Gaertn. [74], as well as other members of the genus Eschweilera (e.g., E. tetrapetela S.A. Mori [63]). This form of phenology could allow individual plants to maximize effective energy investment in reproduction, both in terms of attractiveness to pollinators, and as a means of diminishing proportion of (energetically-demanding) produced seed crop lost to seed predators. This is known from several other igapó species, including A. latifolia Spruce ex Benth. and C. pentandra [74]. This set of adaptations allows for successful colonization by E. tenuifolia in this extreme ecosystem and will be the subject of future studies. 


\section{Conclusions}

Insect infestation of buds can play an important role in regulating flower:fruit ratios, thus setting limits on individual total seed set. Individual E. tenuifolia appear to invest highly in reproduction every second year. Extended flower duration (up to 5 days, rather than 1 day as common in the genus) may be a strategy to enhance pollination success, but it also increases overall reproductive investment via continued nectar production. Abortion of heavily infested buds may minimize allocation of energy to otherwise malformed flowers, which are likely to have lower change in attracting pollinators. Such a strategy functions to save energy in the short term. Additionally, biennial peaks of investment in flowering by individual E. tenuifolia are likely to be an energy-conserving response in a highly physiologically-challenging environment. Thus, E. tenuifolia exhibits energy-conservation strategies at two divergent temporal scales.

Author Contributions: Conceptualization, A.A.B., S.A.B. and T.C.d.S.-B.; methodology, A.A.B. and B.M.B.; software, S.A.B. and T.T.C.; formal analysis, S.A.B. and T.T.C.; investigation, A.A.B. and B.M.B.; resources, A.A.B., B.M.B., S.A.B. and T.T.C.; data curation, A.A.B., S.A.B. and T.T.C.; writing-original draft preparation, A.A.B., S.A.B. and B.M.B.; writing-review and editing, A.A.B., S.A.B., N.M.K., T.C.d.S.-B., T.T.C., M.T.F.P., P.P. and B.M.B.; visualization, S.A.B., T.T.C., N.M.K. and T.C.d.S.-B.; supervision, A.A.B. and S.A.B.; project administration, A.A.B. and S.A.B.; funding acquisition, A.A.B. and B.M.B. All authors have read and agreed to the published version of the manuscript.

Funding: Funding was provided by the American Society of Primatologists, the Columbus Zoo Conservation Fund, the Sophie Danforth Conservation Fund, the LSB Leakey Foundation (US), the Leakey Fund (UK), the MIL Fund (Laurie Shapley), the Margot Marsh Foundation, the Oregon Zoo Conservation Fund, the Percy Sladen Memorial Fund, the Pittsburgh Zoo and Aquarium Conservation Fund, the Primate Action Fund, the Primate Conservation Inc., the Primate Society of Great Britain, Roehampton University, and the Wildlife Conservation Society (all to A.A.B.). B.M.B. was supported by a University of Bristol ORS grant, the Rufford Foundation and Idea Wild at the time of data collection. M.T.F.P. acknowledges PELD-MAUA (CNPq/FAPEAM) for financial and infrastructural support. A.A.B. is currently a CAPES-APNS grant holder (code 001), and B.M.B., is supported by CNPq productivity grant 309256/2019-4 and by FACEPE grants APQ o143-2.04/14; BTF-0160-2.04/17 and BTF-0014-2.05/20.

Acknowledgments: We dedicate this paper to Scott Mori (1941-2020), in recognition of his extraordinary work with Lecthidaceae, and to mourn his recent passing. We thank Eduardo do Souza and Roberto Moreira, Maria do Jesus, field guides for the Jaú component of the study; Rebecca L. Shapley and Welma S. da Silva Carneiro for botanical field help; Daniel Praia and Naara Ferreira da Silva for sharing images. Fabricio Baccaro identified the ants, Mike Hopkins identified the beetles and John Wetzel identified the wasp nest. This is Contribution \# 54 from the Amazon Mammals Research Group, and \# 40 from the Igapó Study Project.

Conflicts of Interest: The authors declare no conflict of interest. The funders had no role in the design of the study; in the collection, analyses, or interpretation of data; in the writing of the manuscript, or in the decision to publish the results.

\section{References}

1. Mori, S.A.; Tsou, C.-H.; Wu, C.-C.; Cronholm, B.; Anderberg, A.A. Evolution of Lecythidaceae with an emphasis on the circumscription of neotropical genera: Information from combined $n d h F$ and $\operatorname{trnL}-F$ sequence data. Am. J. Bot. 2007, 94, 289-301. [CrossRef] [PubMed]

2. Mori, S.A.; Prance, G.T. Lecythidaceae-Part II. The zygomorphic-flowered New World genera (Couroupita, Corythophora, Bertholletia, Couratari, Eschweilera, \& Lecythis). Flora Neotrop. Monogr. 1990, 21, 1-376.

3. Mori, S.A.; Prance, G.T. Taxonomy, ecology, and economic botany of the Brazil nut (Bertholletia excelsa Humb. \& Bonpl.: Lecythidaceae). Econ. Bot. 1990, 8, 130-150.

4. Tropicos. Available online: www.tropicos.org/Name/40006169 (accessed on 11 January 2020).

5. Prance, G.T.; Rodrigues, W.A.; da Silva, M.F. Inventário florestal de um hectare de mata de terra firme km 30 da Estrada Manaus-Itacoatiara. Acta Amaz. 1976, 6, 9-35. [CrossRef]

6. Filho, D.A.L.; de Almeida Matos, F.D.; Amaral, I.; Revilla, J.; Coêlho, L.d.S.; Ramos, J.F.; dos Santos, J.L. Inventário florístico de floresta ombrófila densa de terra firme, na região do Rio Urucu-Amazonas, Brasil. Acta Amaz. 2001, 31, 565. [CrossRef]

7. Matta, L.B.V.; Scudeller, V.V. Lecythidaceae Poit. in the Tupé Sustainable Development Reserve, Manaus, Brazil. Braz. J. Bot. 2012, 35, 195-217. [CrossRef] 
8. Mori, S.A.; Lepsch-Cunha, N. The Lecythidaceae of a central Amazonian moist forest. Mem. N. Y. Bot. Gard. $1995,75,1-55$.

9. De Oliveira, A.A.; Mori, S.A. A central Amazonian terra firme forest. I. High tree species richness on poor soils. Biodivers. Conserv. 1999, 8, 1219-1244. [CrossRef]

10. Carneiro, V.M.C. Composição Florística e Análise Estrutural da Floresta Primária de Terra Firme na Bacia do Rio Cuieiras, Manaus-AM. Master's Thesis, Instituto Nacional de Pesquisas da Amazônia, Manaus, Brazil, 2004.

11. ter Steege, H.; Pitman, N.C.A.; Sabatier, D.; Baraloto, C.; Salomao, R.P.; Guevara, J.E.; Phillips, O.L.; Castilho, C.V.; Magnusson, W.E.; Molino, J.-F.; et al. Hyperdominance in the Amazonian tree flora. Science 2013, 342, 1243092. [CrossRef]

12. Barnett, A.A. Diet, Habitat Use and Conservation Ecology of the Golden-Backed Uacari, Cacajao melanocephalus ouakary, in Jaú National Park, Amazonian Brazil. Ph.D. Thesis, University of Roehampton, London, UK, 2010.

13. Barnett, A.A.; de Castilho, C.V.; Shapley, R.L.; Anicácio, A. Diet, habitat selection and natural history of Cacajao melanocephalus ouakary in Jaú National Park, Brazil. Int. J. Primatol. 2005, 26, 949-969. [CrossRef]

14. Julião, G.R. Riqueza e Abundância de Insetos Galhadores Associados ao Dossel Florestas de Terra Firme, Várzea e Igapó da Amazônia Central. Ph.D. Thesis, Instituto Nacional de Pesquisas da Amazônia and Universidade Federal do Amazonas, Manaus, Brazil, 2007.

15. Aguiar, D.P.P. Influência Dos Fatores Hidro-Edáficos na Diversidade, Composição Florística e Estrutura da Comunidade Arbórea de Igapó no Parque Nacional do Jaú, Amazônia Central. Master's Thesis, Instituto Nacional de Pesquisas da Amazônia, Manaus, Brazil, 2015.

16. Taylor, P.G.; Cesari, I.M.; Arsenak, M.; Ballen, D.; Abad, M.J.; Fernández, A.; Milano, B.; Ruiz, M.-C.; Williams, B.; Michelangeli, F. Evaluation of Venezuelan medicinal plant extracts for antitumor and antiprotease activities. Pharm. Biol. 2006, 44, 349-362. [CrossRef]

17. Barnett, A.A.; Almeida, T.; Spironello, W.R.; Sousa Silva, W.; MacLarnon, A.; Ross, C. Terrestrial foraging by Cacajao melanocephalus ouakary (Primates) in Amazonian Brazil: Is choice of seed patch size and position related to predation risk? Folia Primatol. 2012, 83, 126-139. [CrossRef] [PubMed]

18. Barnett, A.A.; Boyle, S.A.; Pinto, L.P.; Lourenço, W.C.; Almeida, T.; Sousa Silva, W.; Ronchi-Teles, B.; Bezerra, B.M.; Ross, C.; MacLarnon, A.; et al. Primary seed dispersal by three Neotropical seed-predating primates (Cacajao melanocephalus ouakary, Chiropotes chiropotes and Chiropotes albinasus). J. Trop. Ecol. 2012, 28, 543-555. [CrossRef]

19. Antunes, A.C.; Baccaro, F.; Barnett, A.A. What bite marks can tell us: Use of on-fruit tooth impressions to study seed consumer identity and consumption patterns within a rodent assemblage. Mamm. Biol. 2017, 82, 74-79. [CrossRef]

20. Antunes, A.C.; Baccaro, F.; Caetano Andrade, V.L.; Ramos, J.F.; Da Silva Moreira, R.; Barnett, A.A. Igapó seed patches: A potentially key resource for terrestrial vertebrates in a seasonally flooded forest of central Amazonia. Biol. J. Linn. Soc. 2019, 128, 460-472. [CrossRef]

21. Barnett, A.A.; Sampaio, E.M.; Kalko, E.K.V.; Shapley, R.L.; Fischer, E.; Camargo, G.; Rodríguez-Herrera, B. Bats of Jaú National Park, central Amazônia, Brazil. Acta Chiropterologica 2006, 8, 103-128. [CrossRef]

22. Rengifo, E.M.; Calderón, W.; Aquino, R. Características de refugios de algunas especies de murciélagos en la cuenca alta del río Itaya, Loreto, Perú. URJ 2013, 5, 143-150. [CrossRef]

23. Kubitzki, K.; Ziburski, A. Seed dispersal in flood plain forests of Amazonia. Biotropica 1994, 26, 30. [CrossRef]

24. Da Silva, J.A.M.; Pereira-Filho, M.; de Oliveria-Pereira, M.I. Valor nutricional e energético de espécies vegetais importantes na alimentação do tambaqui. Acta Amaz. 2003, 33, 687-700. [CrossRef]

25. Da Silva, J.A.M.; Pereira Filho, M.; de Oliveira-Pereira, M.I. Frutos e sementes consumidos pelo tambaqui, Colossoma macrompum (Cuvier, 1818) incorporados em rações: Digestibilidade e velocidade de trânsito pelo trato gastrointestinal. R. Bras. Zootec. 2003, 32, 1815-1824. [CrossRef]

26. Volkmer-Ribeiro, C.; Becker Maciel, S. New freshwater sponges from Amazonian waters. Amazoniana 1983, 82, 255-264.

27. Manconi, R.; Pronzato, R. Gemmules as a key structure for the adaptive radiation of freshwater sponges: A morphofunctional and biogeographical study. Porifera Res. 2007, 28, 61-77.

28. Höfer, H.; Brescovit, A.D. A revision of the Neotropical spider genus Ancylometes Bertkau (Araneae: Pisauridae). Insect. Syst. Evol. 2000, 31, 323-360. [CrossRef]

29. MacKay, W.P. A review of the new world ant of the genus Dolichoderus. Sociobiology 1993, 22, 1-148. 
30. Barnett, A.A.; Ronchi-Teles, B.; Almeida, T.; Deveny, A.; Schiel-Baracuhy, V.; Souza-Silva, W.; Spironello, W.; Ross, C.; MacLarnon, A. Arthropod predation by a specialist seed predator, the golden-backed uacari (Cacajao melanocephalus ouakary, Pitheciidae) in Brazilian Amazonia. Int. J. Primatol. 2013, 34, 470-485. [CrossRef]

31. Maia, L.A. Influência do Pulso de Inundação na Fisiologia, Fenologia e Produção de Frutos de Hevea spruceana (Euphorbiaceae) e Eschweilera tenuifolia (Lecythidaceae) em Área Inundável de Igapó da Amazônia Central. Ph.D. Thesis, Instituto Nacional de Pesquisas da Amazônia and Universidade Federal do Amazonas, Manaus, Brazil, 1997.

32. Rezende, A.C.C.; Absy, M.L.; Ferreira, M.G.; Marinho, H.A.; Santos, O.d.A. Pollen of honey from Melipona seminigra merrillae Cockerell, 1919, Scaptotrigona nigrohirta Moure, 1968 and Scaptotrigona sp. Moure, 1942 (Apidae: Meliponini) reared in Sataré Mawé indigenous communities, Amazon, Brazil. Palynology 2019, 43, 255-267. [CrossRef]

33. Sánchez-Palomino, P.; Rivas-Pava, P.; Cadena, A. Composición, abundancia y riqueza de especies de la comunidad de murciélagos en bosques de galería en la Serranía de La Macarena. Caldasia 1993, 17, 301-312.

34. Goulding, M. The Fishes and the Forest; University of California Press: Berkeley, CA, USA, 1980.

35. Tsou, C.-H.; Mori, S.A. Seed coat anatomy and its relationship to seed dispersal in subfamily Lecythidoideae of the Lecythidaceae (the Brazil nut family). Bot. Bull. Acad. Sin. 2002, 43. [CrossRef]

36. Harms, K.E.; Aiello, A. Seed-boring by tropical clearwing moths (Sesiidae): Aberrant behavior or widespread habit? J. Lepid. Soc. 1995, 49, 43-48.

37. Eichlin, T.D. A new Panamanian clearwing moth (Sesildae: Sesiinae). J. Lepid. Soc. 1995, 49, $39-42$.

38. Caldwell, J.P. Brazil nut fruit capsules as phytotelmata: Interactions among anuran and insect larvae. Can. J. Zool. 1993, 71, 1193-1201. [CrossRef]

39. Yanoviak, S.P. Distribution and abundance of Microvelia cavicola Polhemus (Heteroptera: Veliidae) on Barro Colorado Island, Panama. J. N. Y. Entomol. Soc. 1999, 107, 38-45.

40. Parolin, P. Diversity of adaptations to flooding in trees of Amazonian floodplains. Pesqui. Bot. 2012, 63, 7-28.

41. Frank, J.H.; Lounibos, L.P. Insects and allies associated with bromeliads: A review. Terr. Arthropod. Rev. 2009, 1, 125-153. [CrossRef]

42. Quaresma, A.C.; Piedade, M.T.F.; Feitosa, Y.O.; Wittmann, F.; ter Steege, H. Composition, diversity and structure of vascular epiphytes in two contrasting Central Amazonian floodplain ecosystems. Acta Bot. Bras. 2017, 31, 686-697. [CrossRef]

43. Quaresma, A.C.; Piedade, M.T.F.; Wittmann, F.; ter Steege, H. Species richness, composition, and spatial distribution of vascular epiphytes in Amazonian black-water floodplain forests. Biodivers Conserv. 2018, 27, 1981-2002. [CrossRef]

44. Barthlott, W.; Porembski, S.; Kluge, M.; Hopke, J.; Schmidt, L. Selenicereus wittii (Cactaceae): An epiphyte adapted to Amazonian igapó inundation forests. Plant Syst. Evol. 1997, 206, 175-185. [CrossRef]

45. Martins, A.C.; Bochorny, T.; Pérez-Escobar, O.A.; Chomicki, G.; Monteiro, S.H.N.; de Camargo Smidt, E. From tree tops to the ground: Reversals to terrestrial habit in Galeandra orchids (Epidendroideae: Catasetinae). Mol. Phylogenetics Evol. 2018, 127, 952-960. [CrossRef]

46. Kleinfeldt, S.E. Ant-gardens: The interaction of Codonanthe crassifolia (Gesneriaceae) and Crematogaster longispina (Formicidae). Ecology 1978, 59, 449-456. [CrossRef]

47. Serrano-Serrano, M.L.; Perret, M.; Guignard, M.; Chautems, A.; Silvestro, D.; Salamin, N. Decoupled evolution of floral traits and climatic preferences in a clade of Neotropical Gesneriaceae. BMC Evol. Biol. 2015, 15, 247. [CrossRef]

48. Kuijt, J.; Hansen, B. Balanophoraceae. In Flowering Plants. Eudicots Santalales, Balanophorales (The Families and Genera of Vascular Plants Book 12); Kubitzski, K., Ed.; Springer: Cham, Switzerland, 2015; pp. 193-208.

49. Gomez, L.D. Parasitic plants. In Costa Rican Natural History; Janzen, D.H., Ed.; University of Chicago Press: Chicago, IL, USA, 1983; pp. 292-298.

50. Ferrer, M.S.; Marvaldi, A.E.; Sato, H.A.; Gonzalez, A.M. Biological notes on two species of Oxycorynus (Coleoptera: Belidae) associated with parasitic plants of the genus Lophophytum (Balanophoraceae), and new distribution records in Argentina. Rev. Soc. Entomológica Argent. 2011, 70, 351-355.

51. Barnett, A.A.; Silva, W.S.; Shaw, P.J.A.; Ramsay, P.M. Inundation duration and vertical vegetation zonation: A preliminary description of the vegetation and structuring factors in borokotóh (hummock igapó), an overlooked, high-diversity, Amazonian vegetation association. Nord. J. Bot. 2015, 33, 601-614. [CrossRef] 
52. Ferreira, L.V.; Stohlgren, T.J. Effects of river level fluctuation on plant species richness, diversity, and distribution in a floodplain forest in central Amazonia. Oecologia 1999, 120, 582-587. [CrossRef] [PubMed]

53. Junk, W.J.; Wittmann, F.; Schöngart, J.; Piedade, M.T.F. A classification of the major habitats of Amazonian black-water river floodplains and a comparison with their white-water counterparts. Wetl. Ecol. Manag. 2015, 23, 677-693. [CrossRef]

54. Resende, A.F.; Piedade, M.T.F.; Feitosa, Y.O.; Andrade, V.H.F.; Trumbore, S.E.; Durgante, F.M.; Macedo, M.O.; Schöngart, J. Flood-pulse disturbances as a threat for long-living Amazonian trees. New Phytol. 2020, 227, 1790-1803. [CrossRef] [PubMed]

55. Junk, W.J.; Bayley, P.B.; Sparks, R.E. The flood pulse concept in river-floodplain systems. Can. Spec. Publ. Fish. Aquat. Sci. 1989, 106, 110-127.

56. Maia, L.A.; Piedade, M.T.F. Phenology of Eschweilera tenuifolia (Lecythidaceae) in flooded forest of the Central Amazonia, Brazil. Neotrop. Ecosyst. Proc. Ger. Braz. Workshop 2002, 4, 1-4.

57. Mori, S.A.; Prance, G.T.; Bolten, A.B. Additional notes on the floral biology of neotropical Lecythidaceae. Brittonia 1978, 30, 113. [CrossRef]

58. Prance, G.T. The pollination and androphore structure of some Amazonian Lecythidaceae. Biotropica 1976, 8, 235. [CrossRef]

59. Gamboa-Gaitán, M.A. Biologia reproductiva de Eschweilera bogotensis (Lecythidaceae), en la cordillera occidental de Colombia. Caldasia 1997, 19, 479-485.

60. Prance, G.T.; Idrobo, J.M.; Castaño, O.V. Mecanismos de polinización de Eschweilera garagarae Pittier en El Chocó, Colombia. Mutilisia 1983, 60,1-7.

61. De Potascheff, C.M.; Mori, S.A.; Lombardi, J.A. Pollination ecology of the Cerrado species Eschweilera nana (Lecythidaceae subfam. Lecythidoideae). Brittonia 2014, 66, 191-206. [CrossRef]

62. Mori, S.A. Biologia da polinização em Lecythidaceae. Acta Bot. Bras. 1987, 1, 121-124. [CrossRef]

63. Menezes, I.S.; do Couto-Santos, A.P.L.; Funch, L.S. The influence of El Niño and edge effects on the reproductive phenology and floral visitors of Eschweilera tetrapetala Mori (Lecythidaceae), an endemic species of the Atlantic Forest of northeastern Brazil. Acta Bot. Bras. 2018, 32, 1-11. [CrossRef]

64. Krause, L. Floral Biology, Flowering Phenology and Floral Visitors of Five Insect-Pollinated Tree Species in a Tropical Lowland Rainforest Remnant of Pernambuco, Brazil. Ph.D. Thesis, University of Ulm, Ulm, Germany, 2008.

65. De Potascheff, C.M. Ecologia da Polinização de Eschweilera nana Miers., Uma Lecythidaceae do Cerrado. Master's Thesis, Universidade Estadual Paulista-Rio Claro, São Paulo, Brazil, 2010.

66. Rego, J.O.; Oliveira, R.; Jacobi, C.M.; Schlindwein, C. Constant flower damage caused by a common stingless bee puts survival of a threatened buzz-pollinated species at risk. Apidologie 2018, 49, 276-286. [CrossRef]

67. Dos Santos, C.F.; Boff, S. Subtle visits despite guards: Theft from nest of stingless bee (Meliponini) by orchid bee (Euglossini). Entomol. Res. 2010, 40, 233-235. [CrossRef]

68. Santos, C.F.; Absy, M.L. Polinizadores de Bertholletia excelsa (Lecythidales: Lecythidaceae): Interações com abelhas sem ferrão (Apidae: Meliponini) e nicho trófico. Neotrop. Entomol. 2010, 39, 854-861. [CrossRef]

69. Morton, C.M.; Mori, S.A.; Prance, G.T.; Karol, K.G.; Chase, M.W. Phylogenetic relationships of Lecythidaceae: A cladistic analysis using rbcL sequence and morphological data. Am. J. Bot. 1997, 84, 530-540. [CrossRef]

70. Feinstein, J.; Purzycki, K.L.; Mori, S.; Hequet, V.; Berkov, A. Neotropical soldier flies (Stratiomyidae) reared from Lecythis poiteaui in French Guiana: Do bat-pollinated flowers attract saprophiles? J. Torrey Bot. Soc. 2008, 135, 200-207. [CrossRef]

71. Prance, G.T.; Mori, S.A. Observations on the fruits and seeds of neotropical Lecythidaceae. Brittonia 1978, 30, 21. [CrossRef]

72. Nelson, B.W.; Absy, M.L.; Barbosa, E.M.; Prance, G.T. Observations on flower visitors to Bertholletia excelsa H.B.K. and Couratari tenuicarpa A.C. Sm. (Lecythidaceae). Acta Amaz. 1985, 15, 225-234. [CrossRef]

73. Gentry, A.H. Coevolutionary patterns in Central American Bignoniaceae. Ann. Mo. Bot. Gard. 1974, 61, 728-759. [CrossRef]

74. Parolin, P.; Armbruester, N.; Wittmann, F.; Ferreira, L.; Piedade, M.T.F.; Junk, W.J. A review of tree phenology in Central Amazonian floodplains. Pesqui. Botânica 2002, 52, 195-222. 
75. Ferreira, L.V. Efeito do período de inundação na fenologia de Eschweilera parvifolia Martius ex. A.P. de Candolle. (Lecythidaceae) em uma floresta inundável na Amazônia Central. In Historia Natural, Ecologia e Conservação de Algumas Espécies de Plantas e Animais da Amazônia; Cintra, R., Ed.; FAPEAM; EDUA; Instituto Nacional de Pesquisas da Amazônia: Manaus, Brazil, 2004; pp. 27-32.

76. Prance, G.T. Notes on the vegetation of Amazonia III. The terminology of Amazonian forest types subject to inundation. Brittonia 1979, 31, 26. [CrossRef]

77. Ferreira, L.V.; Prance, G.T. Species richness and floristic composition in four hectares in the Jaú National Park in upland forests in Central Amazonia. Biodivers. Conserv. 1998, 7, 1349-1364. [CrossRef]

78. Parolin, P.; Wittmann, F. Tree phenology in Amazonian floodplain forests. In Amazonian Floodplain Forests: Ecophysiology, Biodiversity and Sustainable Management; Junk, W.J., Piedade, M.T.F., Wittmann, F., Schöngart, J., Parolin, P., Eds.; Springer: Dordrecht, The Netherlands, 2010; pp. 105-126.

79. Barnett, A.A.; Jucá, T. Primates of igapó forests. In Igapó: Blackwater Flooded Forests of the Amazon; Myster, R.W., Ed.; Springer: Cham, Switzerland, 2018; pp. 121-133.

80. UNESCO Decision: 27 COM 8C.10; Central Amazon Conservation Complex (Brazil): Novo Airão, Brazil, 2003. Available online: https://whc.unesco.org/en/list/998/ (accessed on 23 September 2020).

81. Vicentini, A. A vegetação ao longo de um gradiente edáfico no Parque Nacional do Jaú. In Janelas para a Biodiversidade no Parque Nacional do Jaú: Uma Estratégia par ao Estudo da Biodiversidade na Amazônia; Borges, S.H., Iwanaga, S., Durigan, C.C., Pineiro, M.R., Eds.; Fundação Vitória Amazônica: Manaus, Brazil, 2004; pp. 117-143.

82. Barnett, A.A.; Schiel, V.; Deveny, A.; Valsko, J.; Spironello, W.R.; Ross, C. Predation on Cacajao ouakary and Cebus albifrons (Primates: Platyrrhini) by harpy eagles. Mammalia 2011, 75, 169-172. [CrossRef]

83. Barnett, A.A.; Borges, S.H.; de Castilho, C.V.; Neri, F.M.; Shapley, R.L. Primates of Jaú National Park, Amazonas, Brazil. Neotrop. Primates 2002, 10, 65-70.

84. Barnett, A.A.; Borges, S.; Castilho, C.V. Golden-backed uacari, Cacajao melanocephalus ouakary, in Jaú National Park, Amazonia, Brazil: Results of a short survey. Primate Eye 2000, 70, 33-37.

85. Bezerra, B.M.; Souto, A.S.; Jones, G. Vocal repertoire of golden-backed uakaris (Cacajao melanocephalus): Call structure and context. Int. J. Primatol. 2010, 31, 759-778. [CrossRef]

86. Bezerra, B.M.; Barnett, A.A.; Souto, A.; Jones, G. Ethogram and natural history of golden-backed uakaris (Cacajao melanocephalus). Int. J. Primatol. 2011, 32, 46-68. [CrossRef]

87. Barnett, A.A.; Almeida, T.; Andrade, R.; Boyle, S.; de Lima, M.G.; MacLarnon, A.; Ross, C.; Silva, W.S.; Spironello, W.R.; Ronchi-Teles, B. Ants in their plants: Pseudomyrmex ants reduce primate, parrot and squirrel predation on Macrolobium acaciifolium (Fabaceae) seeds in Amazonian Brazil. Biol. J. Linn Soc. Lond. 2015, 114, 260-273. [CrossRef]

88. Barnett, A.A.; Bezerra, B.M.; Oliveira, M.; Queiroz, H.; Defler, T.R. Cacajao ouakary in Brazil and Colombia: Patterns, puzzles and predictions. In Evolutionary Biology and Conservation of Titis, Sakis and Uacaris; Veiga, L.M., Barnett, A.A., Ferrari, S.F., Norconk, M.A., Eds.; Cambridge University Press: Cambridge, UK, 2013; pp. 179-195.

89. Mound, L.A. Thysanoptera: Diversity and interactions. Annu. Rev. Entomol. 2005, 50, 247-269. [CrossRef] [PubMed]

90. Lewis, T. Thrips, Their Biology, Ecology and Economic Importance; Academic Press: London, UK, 1973.

91. Bolten, A.B.; Feinsinger, P.; Baker, H.G.; Baker, I. On the calculation of sugar concentration in flower nectar. Oecologia 1979, 41, 301-304. [CrossRef] [PubMed]

92. Mesquida, J.; Marilleau, R.; Pham-Delegue, M.-H.; Renard, M. A study of rapeseed (Brassica napus L. var. oleifera Metzger) flower nectar secretions. Apidologie 1988, 19, 307-318. [CrossRef]

93. Ordano, M.; Ornelas, J.F. The cost of nectar replenishment in two epiphytic bromeliads. J. Trop. Ecol. 2005, 21, 541-547. [CrossRef]

94. Pinheiro, E.; Albuquerque, M. Castanha-do-pará. In BRASIL. Ministério da Agricultura. Livro Anual da Agricultura; Ministério da Agricultura: Brasília, Brazil, 1968; pp. 224-233.

95. Ormond, W.T.; Pinheiro, M.C.B.; Castells, A.R.C.D. A contribution to the floral biology and reproductive system of Couroupita guianensis Aubl. (Lecythidaceae). Ann. Mo. Bot. Gard. 1981, 68, 514. [CrossRef]

96. Aguiar, W.M.; Gaglianone, M.C. Comportamento de abelhas visitantes florais de Lecythis lurida (Lecythidaceae) no norte do estado do Rio de Janeiro. Rev. Bras. Entomol. 2008, 52, 277-282. [CrossRef] 
97. Mori, S.A.; Silva, L.A.M.; Santos, T.S. Observações sobre a fenologia e biologia floral de Lecythis pisonis Cambess. (Lecythidaceae). Rev. Theobroma 1980, 10, 103-111.

98. Holman, E.M.; Oosterhuis, D.M. Cotton photosynthesis and carbon partitioning in response to floral bud loss due to insect damage. Crop Sci. 1999, 39, 1347-1351. [CrossRef]

99. Prasad, R.; Prasad, D. Assessment of economic injury level and economic threshold level of bud fly (Dasyneura lini Barnes) infesting linseed. Intian J. Entomol. 2008, 70, 326-329.

100. Walker, G.P.; Voulgaropoulos, A.L.; Phillips, P.A. Effect of citrus bud mite (Acari: Eriophyidae) on lemon yields. J. Econ. Entomol. 1992, 85, 1318-1329. [CrossRef]

101. Poole, B.C.; Nell, T.A.; Barrett, J.E. Role of carbohydrate depletion and ethylene in flower bud abscission of Hibiscus rosa-sinensis L. HortScience 1990, 25, 1138G-1139G. [CrossRef]

102. Phillips, P.A.; Walker, G.P. Increase in flower and young fruit abscission caused by citrus bud mite (Acari: Eriophyidae) feeding in the axillary buds of lemon. J. Econ. Entomol. 1997, 90, 1273-1282. [CrossRef]

103. Akey, D.H.; Henneberry, T.J. Beet armyworm (Lepidoptera: Noctuidae) behavior and effects on insecticide efficacy in open and closed cotton flowers and boll abscission or damage from flower infestation. J. Econ. Entomol. 1998, 91, 263-266. [CrossRef]

104. Dernisky, A.K.; Evans, R.C.; Liburd, O.E.; Mackenzie, K. Characterization of early floral damage by cranberry tipworm (Dasineura oxycoccana Johnson) as a precursor to reduced fruit set in rabbiteye blueberry (Vaccinium ashei Reade). Int. J. Pest Manag. 2005, 51, 143-148. [CrossRef]

105. Tsou, C.-H. The embryology, reproductive morphology and systematics of Lecythidaceae. Mem. N. Y. Bot. Gard. 1994, 71, 1-110.

106. Frame, D.; Durou, S. Morphology and biology of Napoleonaea vogelii (Lecythidaceae) flowers in relation to the natural history of insect visitors. Biotropica 2001, 33, 458-471. [CrossRef]

107. Armstrong, J.E.; Irvine, A.K. Flowering, sex ratios, pollen-ovule ratios, fruit set, and reproductive effort of a dioecious tree, Myristica insipida (Myristicaceae), in two different rain forest communities. Am. J. Bot. 1989, 76, 74-85. [CrossRef]

108. Hermanutz, L.; Innes, D.; Denham, A.; Whelan, R. Very low fruit: Flower ratios in Grevillea (Proteaceae) are independent of breeding system. Aust. J. Bot. 1998, 46, 465. [CrossRef]

109. Udovic, D. Floral predation of Yucca whipplei (Agavaceae) by the sap beetle, Anthonaeus agavensis (Coleoptera: Nitidulidae). Pan Pac. Entomol. 1986, 62, 55-57.

110. Muniz, D.G.; Freitas, A.V.L.; Oliveira, P.S. Phenological relationships of Eunica bechina (Lepidoptera: Nymphalidae) and its host plant, Caryocar brasiliense (Caryocaraceae), in a Neotropical savanna. Stud. Neotrop. Fauna Environ. 2012, 47, 111-118. [CrossRef]

111. Von Dahl, C.C.; Baldwin, I.T. Deciphering the role of ethylene in plant-herbivore interactions. J. Plant Growth Regul. 2007, 26, 201-209. [CrossRef]

112. Von Dahl, C.C.; Winz, R.A.; Halitschke, R.; Kühnemann, F.; Gase, K.; Baldwin, I.T. Tuning the herbivore-induced ethylene burst: The role of transcript accumulation and ethylene perception in Nicotiana attenuata: Ethylene biosynthesis during herbivory. Plant J. 2007, 51, 293-307. [CrossRef] [PubMed]

113. Jiang, H.; Egli, D.B. Shade induced changes in flower and pod number and flower and fruit abscission in soybean. Agron. J. 1993, 85, 221-225. [CrossRef]

114. Herrera, C.M.; Jordano, P.; Guitián, J.; Traveset, A. Annual variability in seed production by woody plants and the masting concept: Reassessment of principles and relationship to pollination and seed dispersal. Am. Nat. 1998, 152, 576-594. [CrossRef] [PubMed]

115. Wallace, J.B.; Benke, A.C.; Lingle, A.H.; Parsons, K. Trophic pathways of macroinvertebrate primary consumers in subtropical blackwater streams. Arch. Für Hydrobiol. Suppl. 1987, 74, 423-451.

116. Henderson, P.A. Fish of the Amazonian igapó: Stability and conservation in a high diversity-low biomass system. J. Fish Biol. 1990, 37, 61-66. [CrossRef]

117. Csotonyi, J.T.; Addicott, J.F. Competition between mutualists: The role of differential flower abscission in yuccas. Oikos 2001, 94, 557-565. [CrossRef]

118. Zink, A.G.; Rosenheim, J.A. Stage-dependent feeding behavior by western tarnished plant bugs influences flower bud abscission in cotton. Entomol. Exp. Appl. 2005, 117, 235-242. [CrossRef]

119. Andersen, A.N. Impact of insect predation on ovule survivorship in Eucalyptus baxteri. J. Ecol. 1989, 77, 62. [CrossRef] 
120. Gahukar, R.T. Population dynamics of Helicoverpa armigera (Hübner) (Lepidoptera: Noctuidae) on rose flowers in central India. J. Entomol. Res. 2002, 26, 265-276.

121. Galen, C.; Cuba, J. Down the tube: Pollinators, predators, and the evolution of flower shape in the alpine skypilot, Polemonium viscosum. Evolution 2001, 55, 1963-1971. [CrossRef] [PubMed]

122. Lukefahr, M.J.; Rhyne, C. Effects of nectariless cottons on populations of three lepidopterous Insects. J. Econ. Entomol. 1960, 53, 242-244. [CrossRef]

123. Guimaraes, P.R.; Raimundo, R.L.G.; Bottcher, C.; Silva, R.R.; Trigo, J.R. Extrafloral nectaries as a deterrent mechanism against seed predators in the chemically protected weed Crotalaria pallida (Leguminosae). Austral Ecol. 2006, 31, 776-782. [CrossRef]

124. Lev-Yadun, S.; Gould, K.S. Role of anthocyanins in plant defence. In Anthocyanins: Biosynthesis, Functions and Applications; Gould, K., Davies, K., Winefield, C., Eds.; Springer: New York, NY, USA, 2014; pp. 21-48.

125. Kirk, W.D.J. How much pollen can thrips destroy? Ecol. Entomol. 1987, 12, 31-40. [CrossRef]

126. Van Rijn, P.C.J.; Tanigoshi, L.K. Pollen as food for the predatory mites Iphiseius degenerans and Neoseiulus cucumeris (Acari: Phytoseiidae): Dietary range and life history. Exp. Appl. Acarol. 1999, 23, 785-802. [CrossRef]

127. Lara, C.; Ornelas, J.F. Effects of nectar theft by flower mites on hummingbird behavior and the reproductive success of their host plant, Moussonia deppeana (Gesneriaceae). Oikos 2002, 96, 470-480. [CrossRef]

128. Kimmel, T.M.; do Nascimento, L.M.; Piechowski, D.; Sampaio, E.V.S.B.; Nogueira Rodal, M.J.; Gottsberger, G. Pollination and seed dispersal modes of woody species of 12-year-old secondary forest in the Atlantic Forest region of Pernambuco, NE Brazil. Flora Morphol. Distrib. Funct. Ecol. Plants 2010, 205, 540-547. [CrossRef]

129. Schwarz, H.H.; Huck, K. Phoretic mites use flowers to transfer between foraging bumblebees. Insect. Sociaux 1997, 44, 303-310. [CrossRef]

130. Lindquist, E.E.; Moraza, M.L. A new genus of flower-dwelling melicharid mites (Acari: Mesostigmata: Ascoidea) phoretic on bats and insects in Costa Rica and Brazil. Zootaxa 2008, 1685, 1-37. [CrossRef]

131. Marinho, D.; Muniz, D.B.; Azevedo, G.G. Nesting biology of three Megachile (Hymenoptera: Megachilidae) species from Eastern Amazonia, Brazil. Rev. Bras. Entomol. 2018, 62, 97-106. [CrossRef]

132. Galen, C.; Newport, M.E.A. Bumble bee behavior and selection on flower size in the sky pilot, Polemonium viscosum. Oecologia 1987, 74, 20-23. [CrossRef]

133. Andersson, S. Floral display and pollination success in Achillea ptarmica (Asteraceae). Ecography 1991, 14, 186-191. [CrossRef]

134. Pohl, N.; Carvallo, G.; Botto-Mahan, C.; Medel, R. Nonadditive effects of flower damage and hummingbird pollination on the fecundity of Mimulus luteus. Oecologia 2006, 149, 648-655. [CrossRef] [PubMed]

135. Cardel, Y.J.; Koptur, S. Effects of florivory on the pollination of flowers: An experimental field study with a perennial plant. Int. J. Plant Sci. 2010, 171, 283-292. [CrossRef]

136. Brody, A.K.; Mitchell, R.J. Effects of experimental manipulation of inflorescence size on pollination and pre-dispersal seed predation in the hummingbird-pollinated plant Ipomopsis aggregata. Oecologia 1997, 110, 86-93. [CrossRef] [PubMed]

137. Knudsen, J.T.; Mori, S.A. Floral scents and pollination in neotropical Lecythidaceae. Biotropica 1996, $28,42$. [CrossRef]

138. Borrell, B.J. Suction feeding in orchid bees (Apidae: Euglossini). Proc. R. Soc. Lond. B 2004, 271. [CrossRef]

139. Harder, L.D.; Cruzan, M.B. An evaluation of the physiological and evolutionary influences of inflorescence size and flower depth on nectar production. Funct. Ecol. 1990, 4, 559. [CrossRef]

140. Ornelas, J.F.; Ordano, M.; De-Nova, A.J.; Quintero, M.E.; Garland, T. Phylogenetic analysis of interspecific variation in nectar of hummingbird-visited plants. J. Evol. Biol. 2007, 20, 1904-1917. [CrossRef]

141. Hampe, A. Fruit tracking, frugivore satiation, and their consequences for seed dispersal. Oecologia 2008, 156, 137-145. [CrossRef] [PubMed]

142. De Mérona, B.; Rankin-de-Mérona, J. Food resource partitioning in a fish community of the central Amazon floodplain. Neotrop. Ichthyol. 2004, 2, 75-84. [CrossRef]

143. Parolin, P.; Wittmann, F.; Ferreira, L.V. Fruit and seed dispersal in Amazonian floodplain trees-a review. Ecotropica 2013, 19, 15-32.

144. Janzen, D.H. Seed predation by animals. Annu. Rev. Ecol. Syst. 1971, 2, 465-492. [CrossRef]

145. Parolin, P. Functional diversity of plant physiology on extreme sites. J. Plant Biochem. Physiol. $2013,1$. [CrossRef] 
146. Parolin, P. Seed germination and early establishment of 12 tree species from nutrient-rich and nutrient-poor Central Amazonian floodplains. Aquat. Bot. 2001, 70, 89-103. [CrossRef]

147. Ferreira, L.V. Effects of the duration of flooding on species richness and floristic composition in three hectares in the Jaú National Park in floodplain forests in central Amazonia. Biodivers. Conserv. 1997, 6, 1353-1363. [CrossRef]

Publisher's Note: MDPI stays neutral with regard to jurisdictional claims in published maps and institutional affiliations.

(C) 2020 by the authors. Licensee MDPI, Basel, Switzerland. This article is an open access article distributed under the terms and conditions of the Creative Commons Attribution (CC BY) license (http://creativecommons.org/licenses/by/4.0/). 